\title{
Monitoring of the reconstruction process in a high mountainous area affected by a major earthquake and subsequent hazards
}

\author{
Chenxiao Tang ${ }^{1,2}$, Xinlei Liu $^{3}$, Yinghua Cai ${ }^{4}$, Cees Van Westen ${ }^{2}$, Yu Yang ${ }^{3,5}$, Hai Tang ${ }^{3}$, Chengzhang Yang ${ }^{3}$, and \\ Chuan Tang ${ }^{3}$ \\ ${ }^{1}$ Institute of Mountain Hazards and Environment, Chinese Academy of Sciences, Chengdu, PR China \\ ${ }^{2}$ Faculty of Geo-Information Science and Earth Observation (ITC), University of Twente, Twente, the Netherlands \\ ${ }^{3}$ State Key Laboratory of Geohazard Prevention and Geoenvironment Protection (SKLGP), \\ Chengdu University of Technology, Chengdu, PR China \\ ${ }^{4}$ Sichuan Institute of Land and Space Ecological Restoration and Geological Hazard Prevention, Chengdu, PR China \\ ${ }^{5}$ Chengdu Monitoring Station of Geological Environment, Chengdu, PR China
}

Correspondence: Chenxiao Tang (c.tang@imde.ac.cn)

Received: 24 June 2019 - Discussion started: 10 September 2019

Revised: 13 March 2020 - Accepted: 24 March 2020 - Published: 29 April 2020

\begin{abstract}
Recovering from major earthquakes is a challenge, especially in mountainous environments where postearthquake hazards may cause substantial impacts for prolonged periods of time. Although such impacts were reported in the 1923 Great Kantō earthquake and the 1999 ChiChi earthquake, careless reconstruction in hazard-prone areas and consequently huge losses were witnessed following the 2008 Wenchuan earthquake in the Sichuan province of China, as several reconstructed settlements were severely damaged by mass movements and floods. In order to summarize experiences and identify problems in the reconstruction planning, a monitoring of one of the settlements, the town of Longchi, was carried out by image interpretation and field investigation. Seven inventories containing buildings, farmlands, roads and mitigation measures were made to study the dynamics of elements at risk and exposure over a period of 11 years. It was found that the total economic value of the newly reconstructed buildings was several times more than in the preearthquake situation in 2007, because of enormous governmental investment. Postseismic hazards were not sufficiently taken into consideration in the recovery planning before the catastrophic debris flow disaster in 2010 . As a result, the direct economic loss from postseismic disasters was slightly more than the loss caused by the Wenchuan earthquake itself. The society showed an impact-adapt pattern, experiencing losses from disasters and then gaining resistance by abandoning buildings in hazard-prone areas and
\end{abstract}

installing mitigation measures. The locations potentially exposed to postearthquake hazards were summarized, and a possible timetable for reconstruction was proposed. Problems might be encountered in hazard assessment, and possible solutions were discussed.

\section{Introduction}

\subsection{Background}

Major disasters, such as earthquakes, have large impacts on societies, causing massive direct and indirect losses. Large earthquakes may also seriously affect the natural environment, in the form of secondary hazards. In mountainous regions one of the most severe secondary hazards is the triggering of coseismic landslides. These may result in the loss of vegetation and the production of large volumes of landslide deposits, which drastically change the susceptibility of the region to rainfall-induced mass movements and flooding after the earthquake (Fan et al., 2019a, b; Tang et al., 2016; Yang et al., 2018; Guo et al., 2016). An amplification followed by a gradual decay in hazards was witnessed after the 1923 Great Kantō earthquake in Japan (Koi et al., 2008; Nakamura et al., 2000), the 1993 Finisterre Range earthquakes in Papua New Guinea (Marc et al., 2015; Stevens et al., 1998), the 1999 Chi-Chi earthquake in Taiwan (Repub- 
lic of China) (Lin et al., 2006; Shieh et al., 2009; Shou et al., 2011; Chen and Hawkins, 2009) and the 2008 Wenchuan earthquake in PR China (Fan et al., 2018, 2019a; Tang et al., 2016, 2019). The process could last from 6 (Hovius et al., 2011) to about 40 (Nakamura et al., 2000) years.

In addition to the prolonged effect, different postseismic hazard types may interact with each other, forming hazard chains and adding further complexity to the situation. The most commonly witnessed cases include landslides forming barrier lakes which later cause outburst floods (Fan et al., 2012; Dong et al., 2011) or debris flows (Hu and Huang, 2017). Moreover the debris flows can result in river damming and riverbed rising (Ni et al., 2014; Tang et al., 2012; Xu et al., 2012; Fan et al., 2019b), causing floods. A comprehensive summary of postearthquake hazard chains was made by Fan et al. (2019b).

Rebuilding and recovering social functions in such circumstances are difficult tasks, as settlements face continuous threats of landslides, debris flows and flash floods. Based on how risk is calculated (van Westen et al., 2006; Fell, 1993; Varnes, 1984), the amplification of hazards and reconstruction brings sharp changes in risk. Careless planning could result in a large increase in risk and consequently severe losses. It has been reported that postearthquake hazards caused severe damage in Taiwan (Republic of China) after the 1999 Chi-Chi earthquake (Lin et al., 2004; Cheng et al., 2005) and in the Sichuan province of PR China after the 2008 Wenchuan earthquake (Tang et al., 2012; Xu et al., 2012; Zhang and Zhang, 2016), but there is a lack of studies summarizing the experiences and problems encountered during the relief and reconstruction periods. It is also not clearly stated when and where to rebuild in such mountainous regions.

To fill this knowledge gap, we conducted a study concerning the recovery in an area hit by the 2008 Wenchuan earthquake. Seven inventories of elements at risk from satellite images covering a period of 11 years (2007-2018) were generated to study the dynamics of exposure and the recovery process. The aim is to show problems encountered during the recovery process and propose possible solutions in order to provide knowledge for future reconstruction efforts in earthquake-susceptible regions.

\subsection{The Wenchuan earthquake}

The $M_{\mathrm{w}}=7.9$ Wenchuan earthquake occurred on 12 May 2008 in the Sichuan province, affecting an area of $110000 \mathrm{~km}^{2}$, most of which consisted of steep mountains with deeply incised valleys. The earthquake triggered a large number of landslides; estimations varied between 48000 and 200000 (Tanyas et al., 2019; C. Xu et al., 2014; Dai et al., 2011). Around one-third of the 87537 casualties were estimated to have been caused by the landslides and not by ground shaking only (F. Wang et al., 2009). The estimated losses from the earthquake were around USD 115 billion
(Dai et al., 2011). After the relief stage, reconstruction began in 2009, and 19 of the Chinese provinces used at least $1 \%$ of their annual provincial revenue for a period of 3 years to support each one of the affected counties or cities in the recovery process (Huang et al., 2011; UNISDR, 2010; Dunford and Li, 2011; P. Xu et al., 2014). The provinces were asked to provide specialists in planning and design, as well as construction workers. Fast reconstruction progress was witnessed, and reconstruction was completed in 2012.

Extreme rainfall events in the years following the earthquake triggered numerous mass movements, mostly in the form of debris flows, destroying many of the reconstructed buildings. One of the most devastating events occurred in the village of Qingping (Mianzhu county) on 13 August 2010 when two debris flows from the Wenjia watershed destroyed the mitigation measures and buried most of the valley, including newly reconstructed villages and roads (Tang et al., 2012). Another example of a major postearthquake disaster was the debris flow that dammed the Min River which flooded the nearby town of Yingxiu on 14 August 2010 (Xu et al., 2012). A third major disaster occurred on 10 July 2013, when a debris flow formed by a breached landslide dam severely damaged the reconstructed buildings in the village of Qipangou, destroying most of the farmlands ( $\mathrm{Hu}$ and Huang, 2017). The losses caused by these disasters resulted from a lack of experience in postearthquake reconstruction planning.

The catastrophic debris flows were caused by the entrainment of coseismic mass wasting by surface runoff. In the epicentral area of the 2008 Wenchuan earthquake, the massmovement activities were highly active in the first 3 years and then decayed rapidly (Tang et al., 2016; Yang et al., 2017, 2018; Zhang et al., 2016). Similar recovery patterns were also observed in other regions (Li et al., 2016). The decay is not a linear process as it is largely affected by precipitation (Tang et al., 2016; Fan et al., 2019b). On 20 August 2019, debris flows again caused severe damage in the Wenchuan area, suggesting the mass movements were still enhanced.

The Wenchuan earthquake has inspired many studies related to assessing vulnerability and losses (X. Wang et al., 2009; Wu et al., 2012), such as physical (Cui et al., 2013), social (Hu et al., 2010; Kun et al., 2009; Lo and Cheung, 2015; Wang et al., 2015; Yang et al., 2015), environmental (Yang et al., 2017), institutional (Hu et al., 2010) and economic vulnerability (Wu et al., 2012; Zhang et al., 2013). Household vulnerability has been studied in particular by a number of studies (Sun et al., 2010a, b; Zhang, 2016) which included subjective perceptions (Yang et al., 2015), factor analysis of household vulnerability (Wang et al., 2015) and of household income (Sun et al., 2010b), and household vulnerability to poverty (Sun et al., 2010a). Recovery was studied by Dalen et al. (2012) and Wang et al. (2015). But little has been investigated in terms of how effective the reconstruction was and how much property value was exposed to the postearthquake hazards due to careless planning. 
Table 1. Data used for interpretation (Pan is panchromatic image; Mul is multispectral image; RGB is red-green-blue color composite).

* Cell size corresponds to Pan / Mul.

\begin{tabular}{|c|c|c|c|c|}
\hline Data type & Data source & Collection date & $\begin{array}{r}\text { Cell size } \\
(\mathrm{m})\end{array}$ & Band \\
\hline $\begin{array}{l}\text { Satellite } \\
\text { images }\end{array}$ & $\begin{array}{l}\text { QuickBird } \\
\text { IKONOS } \\
\text { Aerial photographs } \\
\text { SPOT-5 } \\
\text { WorldView-2 } \\
\text { WorldView-2 } \\
\text { Pléiades } \\
\text { Pléiades } \\
\text { SPOT-6 } \\
\text { Pléiades }\end{array}$ & $\begin{array}{l}\text { Jul } 2005 \\
\text { Sep } 2007 \\
\text { Jun } 2008 \\
\text { Feb } 2009 \\
\text { Mar } 2010 \\
\text { Apr } 2011 \\
\text { Apr } 2013 \\
\text { Dec } 2014 \\
\text { Apr } 2015 \\
\text { Jun } 2018\end{array}$ & $\begin{array}{r}2.4 \\
1 \\
1 \\
2.5 / 10^{*} \\
0.5 / 2^{*} \\
0.5 / 2^{*} \\
0.5 / 2^{*} \\
0.5 / 2^{*} \\
1.5 \\
0.5 / 2^{*}\end{array}$ & $\begin{array}{l}\text { Mul } \\
\text { RGB } \\
\text { RGB } \\
\text { Pan / Mul } \\
\text { Pan / Mul } \\
\text { Pan / Mul } \\
\text { Pan / Mul } \\
\text { Pan / Mul } \\
\text { RGB } \\
\text { Pan / Mul }\end{array}$ \\
\hline DTM & Aerial lidar & 1999 & 5 & - \\
\hline \multirow{2}{*}{$\begin{array}{l}\text { Landslide } \\
\text { inventory }\end{array}$} & Tang et al. (2016) & 2016 & \multicolumn{2}{|c|}{$\begin{array}{l}\text { Polygon-based vector data with } \\
\text { landslide activity mapped for } \\
\text { five periods (2008-2015) }\end{array}$} \\
\hline & This study & 2018 & \multicolumn{2}{|c|}{$\begin{array}{c}\text { Polygon-based inventory based on } \\
\text { image from June } 2018\end{array}$} \\
\hline
\end{tabular}

\subsection{Study area}

The study was conducted in the Longxi watershed, located within $20 \mathrm{~km}$ of the epicenter of the 2008 Wenchuan earthquake in the Sichuan province of China (Fig. 1). The valley had 2306 permanent residents based on the national census in 2010 (Baidu Encyclopedia, 2016). The area of the watershed is about $89 \mathrm{~km}^{2}$, and the elevation ranges from 810 to $3200 \mathrm{~m}$. The main channel of the Longxi River, which is a tributary of the Min River, has an average yearly discharge of $3.44 \mathrm{~m}^{3} \mathrm{~s}^{-1}$, and the recorded maximum discharge was $300 \mathrm{~m}^{3} \mathrm{~s}^{-1}$. The river flows through the Zipingpu hydropower reservoir which is also one of the major water sources of the province, providing drinking water to the large city of Chengdu (with 16.3 million inhabitants). The climate is subtropical, with average annual precipitation of $1135 \mathrm{~mm}$, of which $80 \%$ occurs from May to September. The highest precipitation takes place in August with a maximum recorded intensity of $83.9 \mathrm{~mm} \mathrm{~h}^{-1}$ (Sichuan Geology Engineering Reconnaissance Institute, 2010).

One of the two major faults that ruptured during the earthquake passes through the area: the Yingxiu-Beichuan fault, which had a horizontal displacement of $4.5 \mathrm{~m}$ and a vertical displacement of $6.2 \mathrm{~m}$ (Gorum et al., 2011). The GuanxianJiangyou fault in the south was ruptured during the earthquake as well (Li et al., 2010). As shown in Fig. 1 the surface ruptures splits into two branches in this region. At $3 \mathrm{~km}$ the surface rupture continues on the eastern side of the watershed. Most of the area is underlain by granite, with some conglomerate distributed in the north and carbonatite and sandstone in the south.

\section{Data and methodology}

In order to monitor the changes in the postearthquake period, we acquired a series of 10 high-resolution $(5-10 \mathrm{~m})$ to very high-resolution $(0.5-2.5 \mathrm{~m})$ satellite images covering the period between 2005 and 2018 (Table 1).

The images were georeferenced with the ERDAS IMAGINE AutoSync Workstation and ArcMap Georeferencing tool. A lidar digital terrain model (DTM) provided by the State Bureau of Surveying and Mapping of China was used to visualize images in a 3-D environment in ArcScene software to assist interpretation. The multitemporal landslide inventories reported in Tang et al. (2016) were used to identify the active landslides over time. An additional landslide inventory was made for 2018 to match with the mapping of the elements at risk in this study using a Pléiades image from June 2018.

Before interpreting built-up areas, we also consulted OpenStreetMap in order to evaluate if data from this platform could be used. Unfortunately, the information in OpenStreetMap was very general for the Wenchuan-earthquakeaffected area and was limited to the main roads and general polygons of settlements. Given the current difficulty of digitizing and storing data in OpenStreetMap from different time periods, we decided to generate our database outside of the platform.

We used the above-mentioned data to interpret and digitize engineered features, including buildings, farmlands, plantations, roads and mitigation works. Inventories were made for the following years: 2007, 2008, 2010, 2011, 2013, 2015 and 2018. The inventory of 2007 was made first; then the 


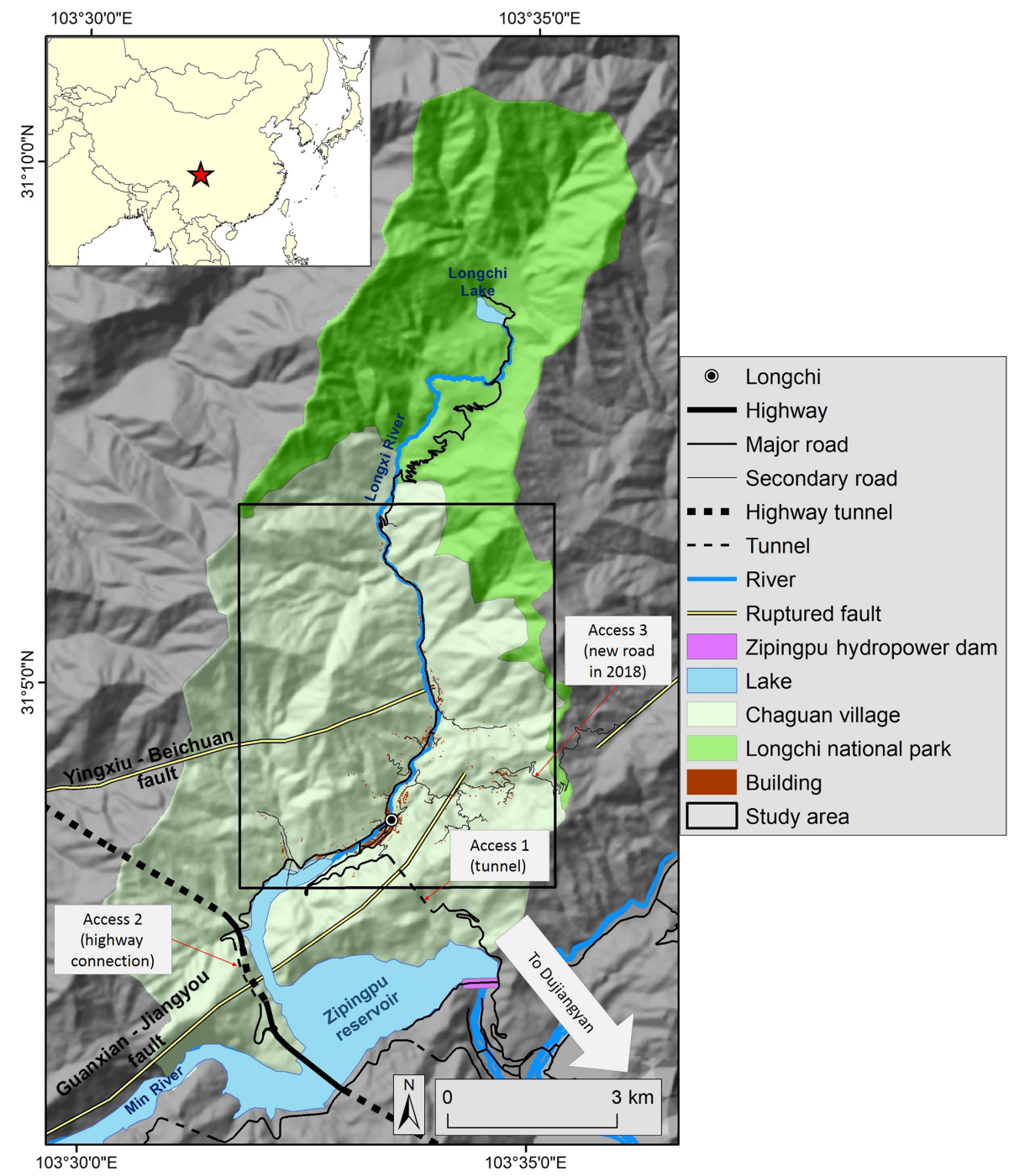

Figure 1. The location of the study area in the Longxi watershed, which contains most of the buildings in the watershed. The roads and buildings reflect the situation in 2018. Buildings outside the study area polygon were not mapped. The inset shows the study area's location within China.

2008 inventory was created based on modifying the earlier inventory using the aerial photograph of 2008 . The inventory of 2010 was derived by modifying the inventory of 2008 using a WorldView-2 image from 2010, the inventory of 2011 was derived from the 2010 inventory and so on. Digitizing in such a manner allowed us to keep consistency among the multitemporal inventories. A series of attributes listed in Table 2 was acquired for the digitized features through image interpretation, field mapping and interviews.

With help from the Chengdu Monitoring Station of Geological Environment, we were able to interview the local authorities about historical events and access some of their documents regarding rural planning and population. Combining their descriptions and records with our field investigation, buildings in this region were classified based on their functions, their construction types and who built them.
Residences are buildings to accommodate locals or workers attending the relief and the reconstruction. Hotels are to provide accommodation and recreation for tourists. Institutional buildings refer to public service buildings like schools, hospitals and water pumping stations. Commercial buildings accommodate shops and local companies. Agricultural buildings are used for storage of livestock, agricultural products and farming equipment. Shelters are temporary residences, including prefabricated houses, tents and shacks.

A total of seven building construction types were found in this region, including three types that served as temporary shelters. Reinforced-concrete frame (RCF; Fig. 2a), reinforced-concrete masonry (RCM; Fig. 2b), wood and brick (WB; Fig. 2c) and wooden (W; Fig. 2d and e) structures were permanent buildings, and prefabricated metal houses (PFM; Fig. 2f), tents (Fig. 2g) and shacks (Fig. 2h) 


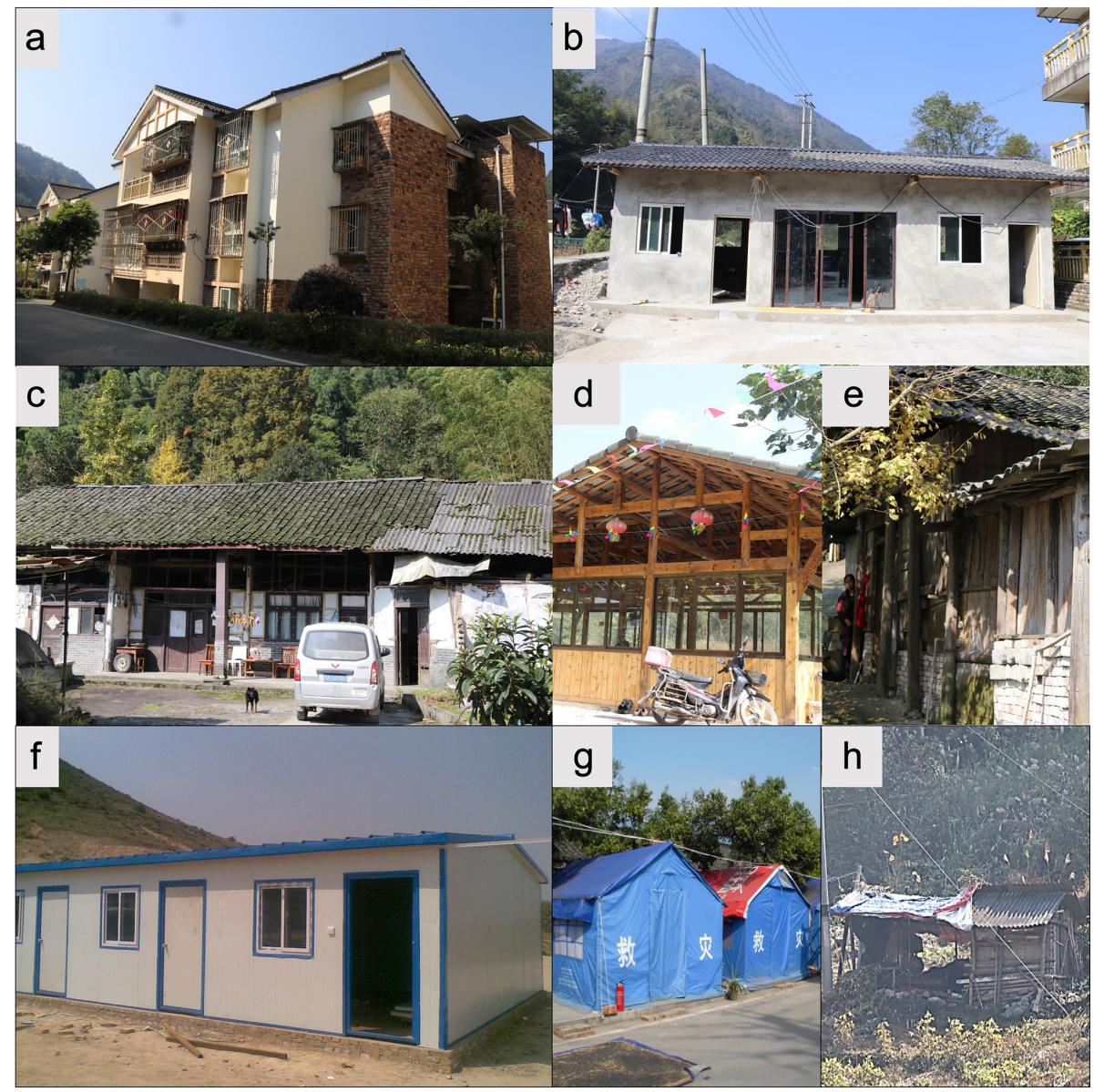

Figure 2. Examples of building construction types in the study area. (a) Reinforced-concrete frame (RCF) residences built by the reconstruction teams from Shanghai. (b) Reinforced-concrete masonry (RCM) building of a hotel. (c) Wood and brick residence (WB). (d) Wooden structure (W) serving as restaurant. (e) Wooden residence with walls made by wooden plates and bricks. (f) Prefabricated metal (PFM) temporary houses. (g) Tents distributed by the government. (h) A shack made from wood, asbestos tiles and waterproof cloth.

served as temporary shelters. Tents and shacks were categorized as one type in this study due to their similar cost and size.

Farmlands were classified into crops for food or commercial crops. Commercial crops were several local plant species, including kiwifruit, tea and Magnolia officinalis, that were widely cultivated and exported to benefit the local economy. Crops for food are the vegetables grown for local consumption.

Roads were categorized into major road, which were wide and built by the national government; secondary road, which were narrower than the major roads and could be either locally built or constructed with help from the government; and dirt road, which were roads without asphalt or a concrete layer. Several bridges and tunnels were mapped as well.

Mitigation works were mapped and were classified into check dams, which block debris flow runout and slow down erosion; drainage channels, which are used to redirect runout of debris flows and floods into rivers directly, avoiding flow through built-up areas; embankments, which are built to shield against debris flow and flood runout; and reinforced slopes, which are stabilized with reinforcement measures and sometimes combined with drainages.

The status of a building is determined by the attributes of damage level, damage type and usage status. The damage level indicates the magnitude of damage a building receives and was assigned based on both image observation and interviewing local people and authorities. If a building was not damaged, level 0 was assigned.

Moderately damaged (level 1) means a disaster-affected building was damaged and restored to its original function after repair.

If a building was damaged beyond repair but did not collapse, it was considered severely damaged (level 2). If a building collapsed, it was classified as destroyed (level 3). The damage type shows what type of hazard feature affected the building, categorized as ground shaking, landslide, debris flow and flooding. Under certain circumstances a build- 
Table 2. Attributes of the elements-at-risk inventories and the main methods of collection (image is image interpretation; mapping is field mapping; interview is interviews with local people and authorities; literature is various published and unpublished sources; calculated is calculated from other attributes).

\begin{tabular}{|c|c|c|c|c|c|c|}
\hline \multirow[t]{2}{*}{ Attributes } & \multirow[t]{2}{*}{ Varieties or descriptions } & \multicolumn{5}{|c|}{ Source } \\
\hline & & 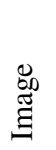 & $\stackrel{\infty}{\cong}$ & 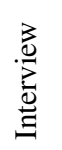 & 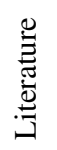 & 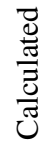 \\
\hline \multicolumn{7}{|l|}{ Buildings } \\
\hline $\begin{array}{l}\text { Construction } \\
\text { types }\end{array}$ & $\begin{array}{l}\text { Permanent buildings - reinforced-concrete frame, } \\
\text { reinforced concrete masonry, wood and brick, wood } \\
\text { Temporary buildings - prefabricated metal, } \\
\text { tents and shacks }\end{array}$ & $\mathrm{x}$ & $\mathrm{x}$ & $\mathrm{x}$ & & \\
\hline Function & $\begin{array}{l}\text { Residence, hotel, institutional, commercial, } \\
\text { agricultural building, shelter }\end{array}$ & & $\mathrm{x}$ & $\mathrm{x}$ & & \\
\hline Builder & Self-constructed, government-build & & $\mathrm{x}$ & $\mathrm{x}$ & & \\
\hline Unit price & $\begin{array}{l}\text { CNY } 150-2700 \text { per square meter, depending on } \\
\text { construction type }\end{array}$ & & & $\mathrm{x}$ & $\mathrm{x}$ & \\
\hline Building floors & $\begin{array}{l}\text { Floors of a building - a maximum of four floors } \\
\text { was allowed }\end{array}$ & & $\mathrm{x}$ & & & \\
\hline Floor space & Building area $\times$ building floors & & & & & $\mathrm{x}$ \\
\hline Value & Floor space $\times$ unit price & & & & & $\mathrm{x}$ \\
\hline \multicolumn{7}{|l|}{ Roads } \\
\hline Type & Major road, secondary road, dirt road, tunnel & $\mathrm{x}$ & $\mathrm{x}$ & & & \\
\hline \multicolumn{7}{|l|}{ Farmlands } \\
\hline Type & Food crops, commercial crops & $\mathrm{x}$ & $\mathrm{x}$ & & & \\
\hline \multicolumn{7}{|c|}{ Mitigation works } \\
\hline Type & $\begin{array}{l}\text { Check dam, drainage channel, embankment, } \\
\text { reinforced slopes }\end{array}$ & $\mathrm{x}$ & $\mathrm{x}$ & & & \\
\hline \multicolumn{7}{|c|}{ All elements at risk } \\
\hline Damage level & $\begin{array}{l}\text { No damage, moderately damage, severely } \\
\text { damaged, destroyed }\end{array}$ & $\mathrm{x}$ & $\mathrm{x}$ & & & \\
\hline Damage type & $\begin{array}{l}\text { Earthquake, slides, debris flows, flood, } \\
\text { no damage }\end{array}$ & $\mathrm{x}$ & $\mathrm{x}$ & $\mathrm{x}$ & & \\
\hline Usage status & Normal, abandoned, empty & $\mathrm{x}$ & $\mathrm{x}$ & & & \\
\hline Geometry & Autocalculated in ArcMap & & & & & $\mathrm{x}$ \\
\hline
\end{tabular}

ing could be affected by more than one hazard type, for instance by ground shaking and landslide impact at the same time. The usage status indicates if a feature was functioning normally (normal), was temporarily not been used (empty) or was completely abandoned (abandoned). It was assigned based on field mapping and interviews. The geometrical attributes (area or length) were calculated automatically in ArcMap, based on the polygon (buildings or land parcels) or line (road) features. Floor space was calculated by multiplying the number of building floors with the footprint area. The unit price was the cost to construct buildings per square meter and was obtained through interviews and literature study. The replacement value of a building was estimated by multiplying the unit price with the floor space. All the economic values in this study were converted to US dollars (USD) with a 10 -year average exchange rate of USD $1=$ CNY 6.51 . 
We investigated economic recovery by interviewing the local inhabitants and village authorities. Unfortunately, most of them were not willing to share information regarding their income; thus we could only make a descriptive analysis. Each of the interviewees represents one family in the analysis. A total of 113 persons were interviewed in 2018.

\section{Monitoring reconstruction}

In this section we monitor the changes in the built-up environment caused by human activities and disasters from 2007 to 2018. The overall statistics are shown in Table 3.

\subsection{The impact of the earthquake (2007-2008)}

A total of 417 buildings in 2007 were identified from visual interpretation (Table 3 and Fig. A1), and most of them were self-built residences. Most buildings were not properly designed to withstand a major earthquake (Table 3). The last major earthquake in this area dates back to 1933 (Diexi earthquake), and there were no eyewitnesses of that event alive anymore in 2007. According to investigation reports, debris flows had not been witnessed in 50 years until the Wenchuan earthquake (Yi et al., 2009; Luo et al., 2010; Sichuan Geology Engineering Reconnaissance Institute, 2010, 2011; Sichuan Geological Survey, 2010).

The 12 May 2008 Wenchuan earthquake triggered 1597 landslides in the study area according to the landslide inventory of Tang et al. (2016). Only a few casualties were reported in this region, as the earthquake occurred at 14:28 LT when most of the inhabitants were working outdoors.

The earthquake affected 444 buildings including some newly built ones in 2008 (Fig. 3). A total of 142 buildings were completely destroyed (damage level 3), of which 29 were destroyed by coseismic landslides. Based on a 2009 SPOT image and 2010 WorldView-2 images, a total of 221 buildings were severely damaged and subsequently removed. The remaining 81 buildings were repaired and functioned normally in 2009 and 2010 and thus were classified as moderately damaged. A summary of the building damage is shown in Table 4.

Overall the significance of the damage-type proportions could only be observed at damage level 1 . There were relatively more single-story buildings (22\%) than two-story buildings $(11 \%)$ that survived. A difference related to construction types was observed, as the survive rates of the RCM, WB and $\mathrm{W}$ types were $23 \%, 17 \%$ and $9 \%$. There were only four RCF buildings, and two survived. The damage-type proportions of the three major construction types (RCM, WB and W) are shown in Fig. 4a.

A damage pattern controlled by fault rupture was found. Building damage was more serious on the hanging wall or within a $1 \mathrm{~km}$ distance of the Yingxiu-Beichuan fault rupture (indicated by a thick dotted line in Fig. 3). The pro- portion of buildings destroyed in the northwest was much higher (Fig. 4b and c) than in the southeast, as only 17 of the 81 buildings that survived are located in the northwest. The damage was not influenced by the construction types in the north, probably indicating the shaking was so strong that it exceeded the resistance of all the three types (Fig. 4b). The southern side showed a significance difference in damage for the construction types, as the RCM buildings had the lowest proportion of collapsed buildings, while wooden buildings had the highest (Fig. 4c). The landslide area density in the northwest is much higher than in the southeast, further suggesting the existence of a localized ground-shaking difference (Fig. 3).

Road stretches with a combined length of $3.7 \mathrm{~km}$, which was $11 \%$ of the local road network of $33.5 \mathrm{~km}$, were blocked by coseismic landslides. The only access road, the tunnel in the southeast (Fig. 1, Access 1), survived the earthquake. None of the farmlands were directly affected by the coseismic landslides, because most of them were located on gentle slopes or flat lands in the southern part of the area.

\subsection{The disaster relief (2009)}

Aerial photos of 2008 and a SPOT image of 2009 were used to map shelters (Fig. 5). Before the government could bring in prefabricated houses, the survivors set up 229 shelters by building shacks and using tents provided by the government. Many constructed the shelters next to their destroyed houses, even when this was very close to coseismic landslides.

The government had problems with identifying suitable locations for the shelter settlements. The lack of awareness of the possible areas endangered by postearthquake landslide and debris flow played an important role in this. Before the winter of 2008 four temporary settlements were made with 82 prefabricated buildings, which housed multiple families (Fig. 5 and Table 3). The largest temporary settlement with prefabricated buildings (PFM) along with some tents and shacks (TSs) was established on the lower part of the alluvial fan of one of the largest subwatersheds, the Bayi catchment, which later posed a high debris flow threat, as $29 \%$ of its watershed area was covered by coseismic landslides (Fig. 5).

It was difficult to estimate the accommodation status of the survivors since many of them went to relatives outside the area and many workers and soldiers moved into the area to carry out the relief efforts.

\subsection{Early reconstruction stage (2009-2010)}

A SPOT image of 2009 and a WorldView-2 image of 2010 were used to map the buildings, roads and mitigation measures for 2010, which illustrate the changes brought by early reconstruction efforts. The city of Shanghai was assigned responsibility for executing the recovery activities of the nearby city of Dujiangyan and the surrounding area, includ- 
Table 3. Number of functioning buildings per function and construction type for the seven time periods considered. Where applicable, the numbers before the parentheses indicate the total number, and the numbers in the parentheses indicate the building numbers built by the government. * Sum of all buildings.

\begin{tabular}{|c|c|c|c|c|c|c|c|c|}
\hline \multirow[t]{2}{*}{ Period } & \multirow[t]{2}{*}{ Function } & \multicolumn{6}{|c|}{ Construction type } & \multirow[t]{2}{*}{ Total } \\
\hline & & $\mathrm{RCF}$ & $\mathrm{RCM}$ & WB & W & PFM & TSs & \\
\hline \multirow{5}{*}{$\begin{array}{l}2007 \text { - } \\
\text { preearthquake } \\
\text { situation }\end{array}$} & Residences & 0 & $66(12)$ & 186 & 51 & 0 & 0 & $304(12)$ \\
\hline & Hotels & 1 & 75 & 10 & 0 & 1 & 0 & 87 \\
\hline & Institutional buildings & $3(3)$ & $1(1)$ & 0 & 0 & 0 & 0 & $4(4)$ \\
\hline & Agricultural buildings & 0 & 0 & 0 & 23 & 0 & 0 & 23 \\
\hline & Total & $4(3)$ & $142(13)$ & 196 & 74 & 1 & 0 & $417(16)^{*}$ \\
\hline \multirow{6}{*}{$\begin{array}{l}2008- \\
\text { shortly } \\
\text { after the } \\
\text { earthquake }\end{array}$} & Residences & 0 & 24 & 40 & 5 & 0 & 0 & 69 \\
\hline & Hotels & 0 & 9 & 0 & 0 & 0 & 0 & 9 \\
\hline & Institutional buildings & $2(2)$ & 0 & 0 & 0 & 0 & 0 & $2(2)$ \\
\hline & Agricultural buildings & 0 & 0 & 0 & 1 & 0 & 0 & 1 \\
\hline & Shelters & 0 & 0 & 0 & 0 & $82(82)$ & 227 & $309(82)$ \\
\hline & Total & $2(2)$ & 33 & 40 & 6 & $82(82)$ & 227 & $390(84)^{*}$ \\
\hline \multirow{7}{*}{$\begin{array}{l}2010- \\
\text { earthquake } \\
\text { reconstruction } \\
\text { almost } \\
\text { completed }\end{array}$} & Residences & $126(118)$ & 78 & 237 & 42 & 0 & 0 & $483(118)$ \\
\hline & Hotels & 77 & 18 & 2 & 3 & 0 & 0 & 100 \\
\hline & Institutional buildings & $25(25)$ & $1(1)$ & 0 & 0 & 0 & 0 & $26(26)$ \\
\hline & Agricultural buildings & 0 & 1 & 1 & 86 & 0 & 0 & 88 \\
\hline & Commercial buildings & $36(32)$ & 2 & 0 & 1 & 0 & 0 & $39(32)$ \\
\hline & Shelters & 0 & 0 & 0 & 0 & $116(116)$ & 21 & 137 (116) \\
\hline & Total & $266(175)$ & $99(1)$ & 239 & 132 & $116(116)$ & 21 & $873(292)^{*}$ \\
\hline \multirow{7}{*}{$\begin{array}{l}2011- \\
\text { after } \\
\text { devastating } \\
\text { debris } \\
\text { flows }\end{array}$} & Residences & $124(116)$ & 65 & 236 & 40 & 2 & 0 & 467 (116) \\
\hline & Hotels & 59 & 12 & 1 & 3 & 0 & 0 & 75 \\
\hline & Institutional buildings & $25(25)$ & $1(1)$ & 0 & 0 & 0 & 0 & $26(26)$ \\
\hline & Agricultural buildings & 0 & 1 & 7 & 86 & 0 & 0 & 94 \\
\hline & Commercial buildings & $36(32)$ & 2 & 0 & 1 & 0 & 0 & $39(32)$ \\
\hline & Shelters & 0 & 0 & 0 & 0 & $50(50)$ & 3 & $53(50)$ \\
\hline & Total & $244(173)$ & $76(1)$ & 229 & 127 & $52(50)$ & 3 & $712(224)^{*}$ \\
\hline \multirow{6}{*}{$\begin{array}{l}2013 \text { - all } \\
\text { reconstruction } \\
\text { completed }\end{array}$} & Residences & $143(132)$ & 56 & 206 & 42 & 3 & 0 & $450(132)$ \\
\hline & Hotels & 68 & 17 & 1 & 3 & 0 & 0 & 89 \\
\hline & Institutional buildings & $20(20)$ & $1(1)$ & 0 & 0 & 0 & 0 & $21(21)$ \\
\hline & Agricultural buildings & 0 & 1 & 2 & 76 & 0 & 0 & 79 \\
\hline & Commercial buildings & $36(32)$ & 2 & 0 & 1 & 0 & 0 & $39(32)$ \\
\hline & Total & 267 (184) & $77(1)$ & 209 & 122 & 3 & 0 & $678(185)^{*}$ \\
\hline \multirow[t]{6}{*}{2015} & Residences & $142(132)$ & 68 & 199 & 45 & 3 & 0 & 457 (132) \\
\hline & Hotels & 69 & 13 & 1 & 3 & 0 & 0 & 86 \\
\hline & Institutional buildings & $19(19)$ & $1(1)$ & 0 & 0 & 0 & 0 & $20(20)$ \\
\hline & Agricultural buildings & 0 & 1 & 6 & 78 & 0 & 0 & 85 \\
\hline & Commercial buildings & $36(32)$ & 2 & 6 & 1 & 0 & 0 & $45(32)$ \\
\hline & Total & $272(183)$ & $85(1)$ & 208 & 127 & 3 & 0 & $693(184)^{*}$ \\
\hline \multirow[t]{6}{*}{2018} & Residences & $142(132)$ & 68 & 199 & 49 & 3 & 0 & $461(132)$ \\
\hline & Hotels & 71 & 13 & 1 & 3 & 0 & 0 & 88 \\
\hline & Institutional buildings & $19(19)$ & $2(2)$ & 0 & 0 & 0 & 0 & $21(21)$ \\
\hline & Agricultural buildings & 0 & 1 & 8 & 77 & 0 & 0 & 86 \\
\hline & Commercial buildings & $36(32)$ & 2 & 4 & 1 & 0 & 0 & $43(32)$ \\
\hline & Total & $268(183)$ & $86(2)$ & 212 & 130 & 3 & 0 & $699(185)^{*}$ \\
\hline
\end{tabular}




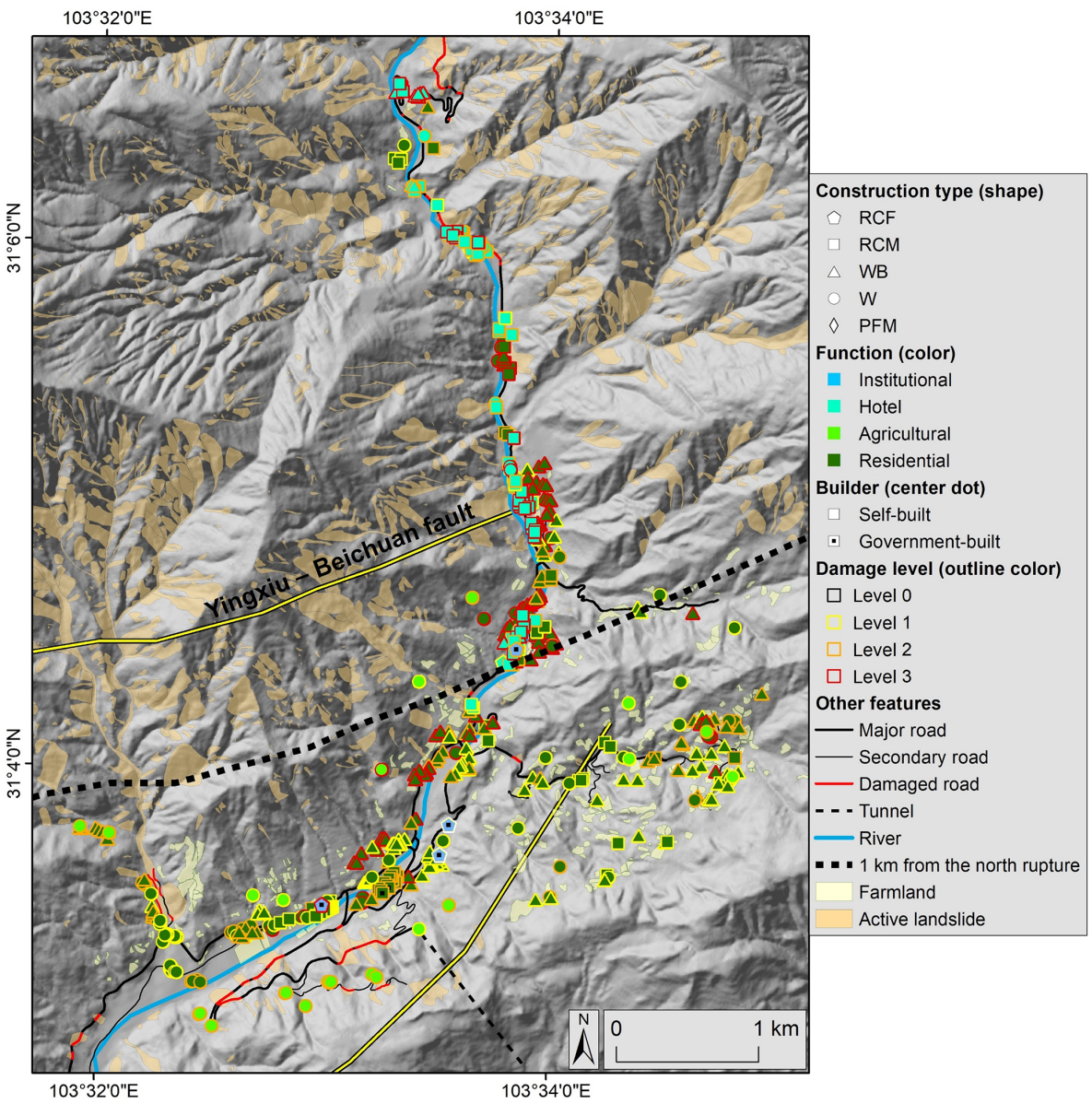

Figure 3. A map showing the damage level of buildings and the distribution of coseismic landslides after the 2008 Wenchuan earthquake. Buildings on the foot wall (southeast) and $1 \mathrm{~km}$ away from the northern fault rupture (indicated by the thick dotted line) suffered significantly less damage.

Table 4. Statistics of building damage caused by the earthquake. The percentage in the parentheses was calculated by the number in the cell divided by the total numbers of the row. ${ }^{*}$ Sum of all affected buildings.

\begin{tabular}{llrrrr}
\hline $\begin{array}{l}\text { Construction } \\
\text { type }\end{array}$ & $\begin{array}{l}\text { Number } \\
\text { of floors }\end{array}$ & Level 1 & $\begin{array}{c}\text { Damage levels } \\
\text { Level 2 }\end{array}$ & Level 3 & $\begin{array}{r}\text { Sum by } \\
\text { floors and } \\
\text { construction } \\
\text { type }\end{array}$ \\
\hline \multirow{2}{*}{ RCF } & One & 2 & 0 & 0 & 2 \\
& Two & 0 & 2 & 0 & 2 \\
\hline \multirow{2}{*}{ RCM } & One & $22(35 \%)$ & $19(30 \%)$ & $22(35 \%)$ & 63 \\
& Two & $11(13 \%)$ & $51(63 \%)$ & $20(24 \%)$ & 82 \\
\hline \multirow{2}{*}{ WB } & One & $34(21 \%)$ & $70(44 \%)$ & $56(35 \%)$ & 160 \\
\hline \multirow{2}{*}{ Two } & $6(9 \%)$ & $38(55 \%)$ & $25(36 \%)$ & 69 \\
\hline \multirow{2}{*}{ Sum by building } & One & $6(10 \%)$ & $38(60 \%)$ & $19(30 \%)$ & 61 \\
floors & Two & $64(22 \%)$ & $127(44 \%)$ & $97(34 \%)$ & 3 \\
\hline \multicolumn{2}{c}{ Sum by damage level } & $17(11 \%)$ & $94(60 \%)$ & $45(29 \%)$ & 156 \\
\hline
\end{tabular}




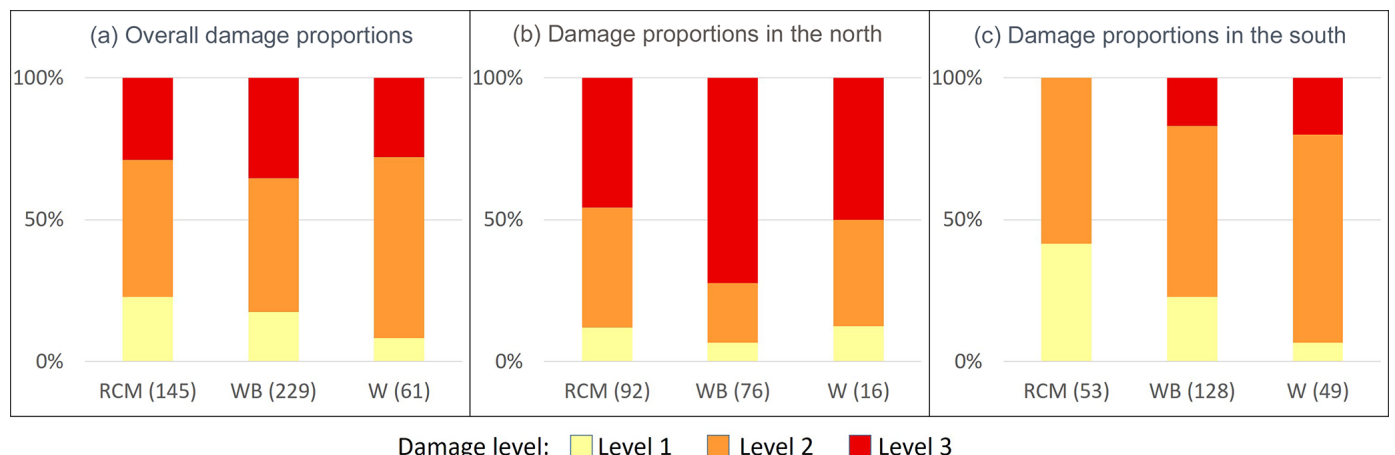

Figure 4. Damage-type proportion statistics of the three major structural types in 2008. The numbers in parentheses under the $x$ axis indicate the total number of buildings. (a) Damage-type proportions of all the earthquake-affected buildings. (b) Damage-type proportions on the northern side of the thick dotted line in Fig. 3. (c) Damage-type proportions on the southern side of the thick dotted line in Fig. 3.

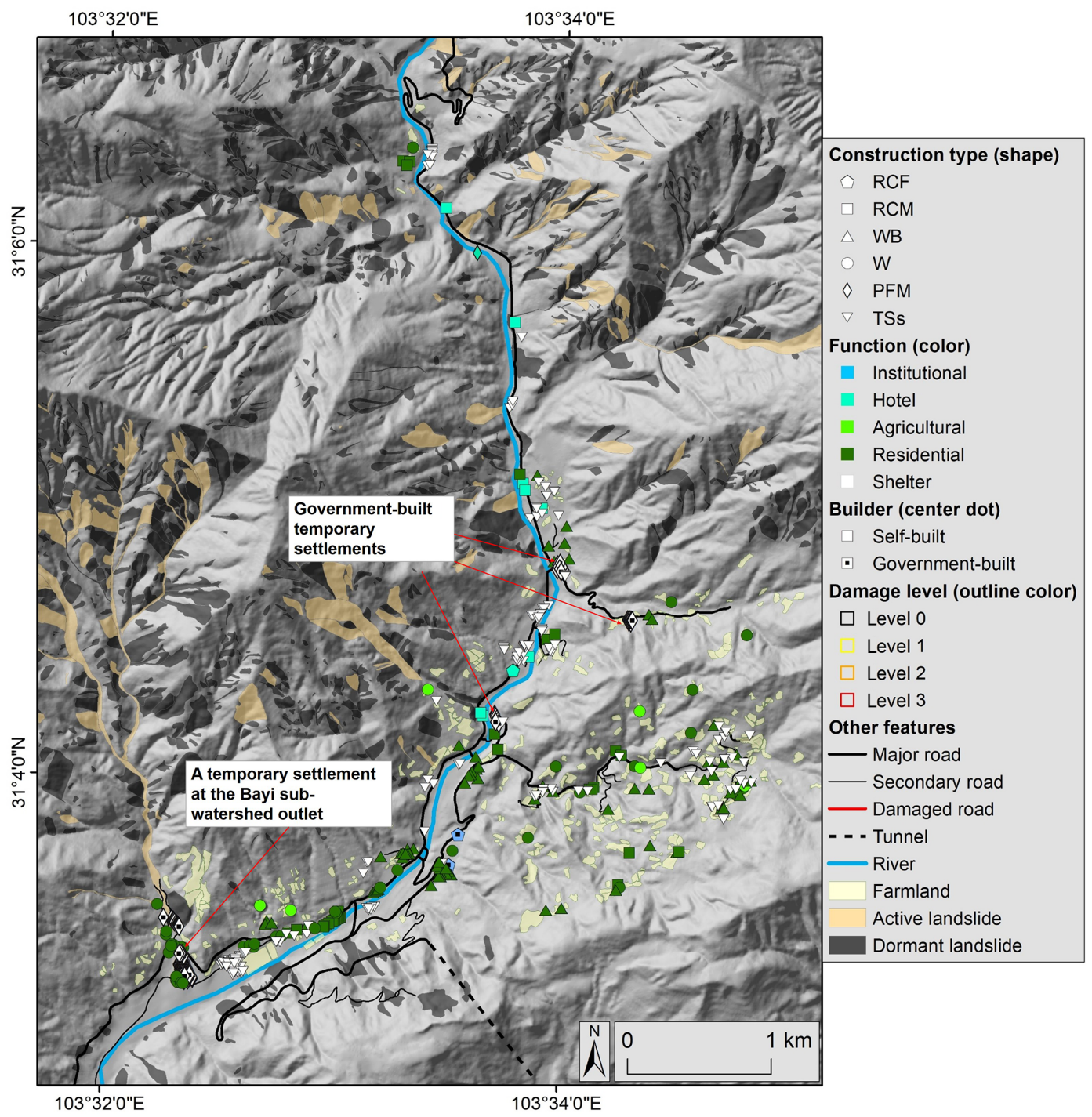

Figure 5. Map of the buildings that survived the earthquake and location of temporary shelters. Many local residents set TSs near their destroyed houses. The government established four PFM temporary settlements, and one of them was located at the outlet of the Bayi catchment, which posed a great debris flow threat due to $29 \%$ of the area being covered by landslides. 
ing the Longchi valley. During this period all rubble was removed as well as most of the tents and shacks.

The new inventory contains 873 buildings, out of which 706 were newly constructed, including some new shelters. Among the 655 reconstructed permanent buildings, 481 were built by the residents themselves with financial support from the government. There were 174 new buildings constructed by the government, and most of them are concentrated in the center of Longchi (Fig. 6), which was proven to be a safe location in the later years. All the road damage was repaired, and a new highway entrance was made in May 2009 (Fig. 1, Access 2, and Fig. 8), which shortened the travel time to Longchi by nearly $40 \mathrm{~min}$ and bypassed some road sections threatened by landslides.

The government implemented a policy to avoid losses in future earthquakes and applied RCF structures in $99 \%$ of the reconstructed buildings. An example of such a governmentbuilt apartment building is shown in Fig. 2a. The construction types for self-built residences did not change significantly, as most of them (278) were built with locally available wood (WB and W construction types). A notable increase in using frame structures among the hotels was observed (Table 3), many of which were rebuilt near the original locations along the Longxi River.

Unfortunately, the lack of knowledge about postearthquake hazards led to many careless decisions made by both the government and the local residents. Many buildings were rebuilt at outlets of subcatchments because historical deposition fans provided relatively flat land. Most of the rebuilt and newly added hotels were located next to the Longxi River in order to attract tourists, ignoring the potential danger posed by the river.

No major disaster occurred in 2009 , as the precipitation was not significant in this region. Only limited hazard mitigation projects were carried out. Three potentially dangerous slopes near the Longchi town were stabilized during the reconstruction process. After a small debris flow destroyed four PFM shelters during the monsoon of 2009, two check dams and a drainage system were installed in the Bayi subwatershed (Fig. 6).

\subsection{The late reconstruction stage and major debris flow disaster (2011-2013)}

A WorldView-2 image from 2011 was used to map the changes caused by a major debris flow disaster that occurred during 13-14 August 2010 (Fig. 7; Xu et al., 2012; Tang et al., 2012). The event was triggered by a storm on $14 \mathrm{Au}-$ gust 2010 with a maximum recorded rainfall intensity of $75 \mathrm{~mm} \mathrm{~h}^{-1}$ measured by rain gauges in Longchi (Xu et al., 2012). About 341 new landslides were triggered, and 1151 of the coseismic landslides were reactivated in this area during this event, producing several massive debris flows which joined in the valley of the Longxi River (Yu et al., 2011), reaching the Zipingpu reservoir. Sedimentation was 5-7 $\mathrm{m}$ at about $300 \mathrm{~m}$ upstream of the town (Sichuan Geology Engineering Reconnaissance Institute, 2011).

Nearly one-fourth of all buildings in the study were impacted by debris flows and subsequent floods. Among all the 213 affected buildings, 70 were destroyed, 41 were severely damaged and 102 were moderately damaged. The most severe loss occurred at the outlet of the Bayi subcatchment where a large debris flow severely damaged the temporary settlement (Fig. 8a and b). The drainage and the poorly constructed check dams in the Bayi subcatchment constructed in early 2010 did not prove to be adequate and were destroyed (Fig. 8c). The disaster also damaged $35000 \mathrm{~m}^{2}$ of farmlands and destroyed $7.5 \mathrm{~km}$ of road. The losses were largest for those buildings located either near subcatchment outlets (Fig. 8a and d) or close to the river (Fig. 8e and f).

Another inventory was made based on 2011 WorldView2 and 2013 Pléiades images, which represents the situation shortly after the debris flow and the official announcement of reconstruction completion (in 2012; Fig. 9). All the temporary buildings were removed by 2012 . A total of 38 buildings that were threatened by debris flows or floods were abandoned. The government constructed another 25 buildings to replace these, and local people constructed 67 new buildings. The total number of functioning buildings was reduced to 678 (Table 3).

Many mitigation measures, such as check dams, sediment retention basins and debris flow early-warning systems, were implemented, and concrete embankments were installed along parts of the river (Fig. 9). The debris flow warning is based on the accumulative rainfall and rainfall intensity recorded by rain gauges installed in the watershed. A camera was installed in the upper stream of the Longxi river to monitor debris flow and flood activities.

From August 2010 to April 2013 the debris flow activities in most of the subcatchments decayed rapidly except for in the Bayi subcatchment. A flashflood took place in 2013, damaging 20 buildings. A major cause of the floods was the dramatic rise of the riverbed (Yu et al., 2011) brought about by debris flows. The authorities said it was not possible to reopen the Longxi national park due to a high landslide threat along the access road. The maintenance for the major road in the north stopped due to being repeatedly damaged by floods and the closure of the national park. A dirt road was made as a replacement.

\subsection{The postreconstruction stage (2013-2018)}

The changes from 2013 to 2018 were identified by interpreting a 2015 SPOT-6 image and a 2018 Pléiades image (Fig. 10). The society developed in a stable manner without any major disruption; thus we only described the inventory of 2018. In this period, 21 new buildings were constructed by local people. The total number of buildings in the area grew to 699 (Table 3). 


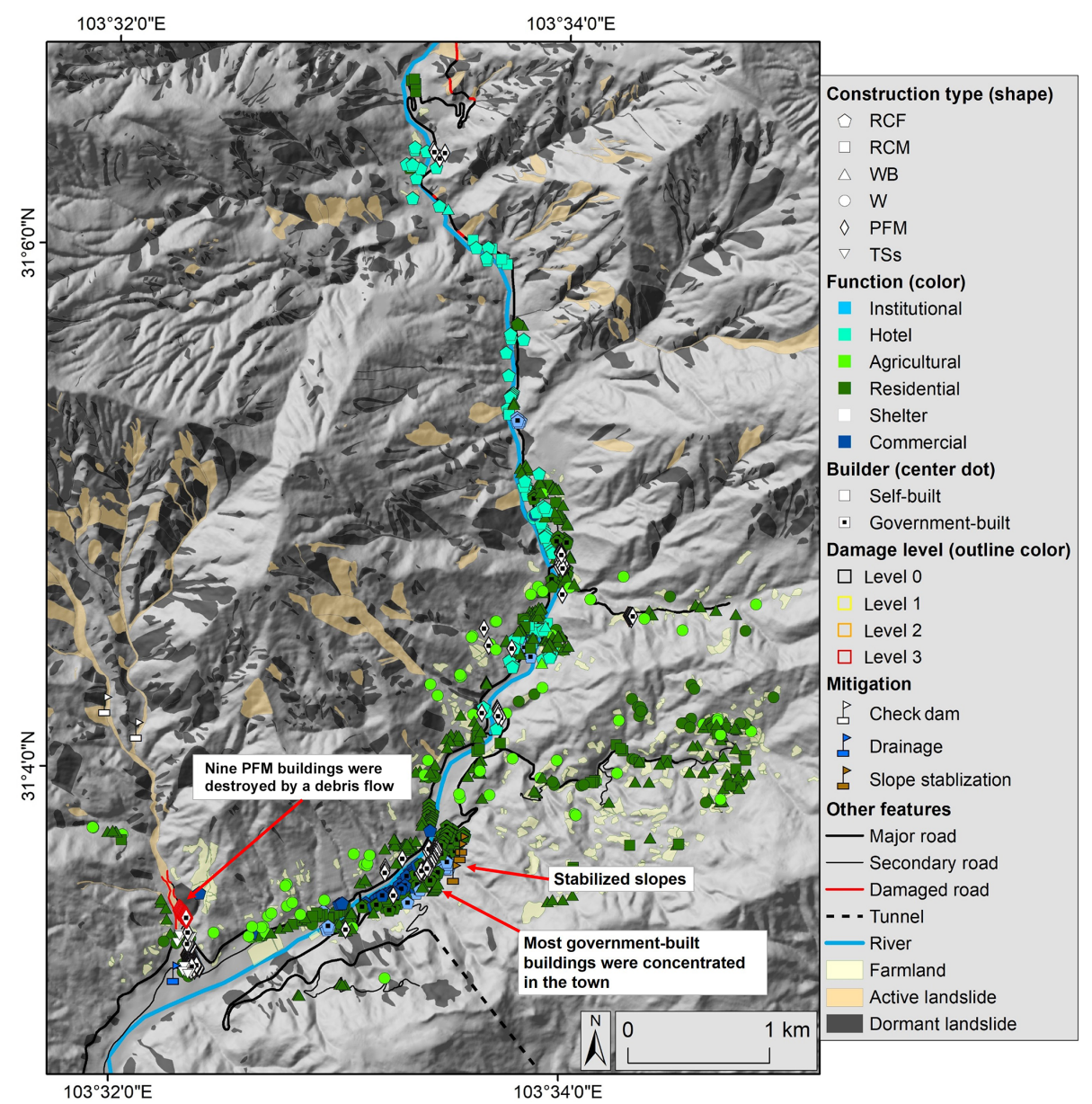

Figure 6. The inventory of the situation in 2010 before the monsoon, showing the buildings, roads and remedial measures for the period between 2008 and 2010. Overlaid are the active landslides in 2009. A debris flow destroyed nine PFM shelters, after which two check dams and a drainage system were installed.

The road length increased to $46.2 \mathrm{~km}$, as many dirt roads were made to access farmlands. The tunnel connecting the highway was closed due to water leakage (Fig. 1, Access 2), and its maintenance was stopped, probably because of low economic benefit caused by the loss of tourism. Only the old tunnel (Fig. 1, Access 1) could be used. A secondary road was made in 2018 connecting the neighboring catchment and provided a second access road for the Longxi watershed (Figs. 1 and 10, Access 3).

Landslides and floods have not caused any major loss since 2013 due to the decaying hazard (Tang et al., 2016) and the mitigation measures. Two elevated drainage channels were installed in 2015 in the southern part to redirect flash floods from subcatchments into the river directly. The last reported disaster was a flood cutting off the dirt road in the north on 20 August 2019.

\section{Analysis of economic values}

In this section the economic values of the built-up features were estimated in US dollars. The total value of the buildings was estimated by multiplying floor space with the unit price for construction. The values and the exposure to debris flows and floods in the seven investigated periods were evaluated.

\subsection{Value estimation}

The unit prices for different building types and roads were acquired through interviews with local builders and local government officers (Table 5). The unit prices of buildings increased after the earthquake due to several reasons: higher building standards, large consumption of building materials in the earthquake-hit areas and currency devaluation. The prices of mitigation structures were estimated based on the mitigation design of a catchment in the neighboring watershed ( $\mathrm{Li}$ et al., 2011). The mitigation structures built after 2010 have a worth of approximately CNY 30 million 


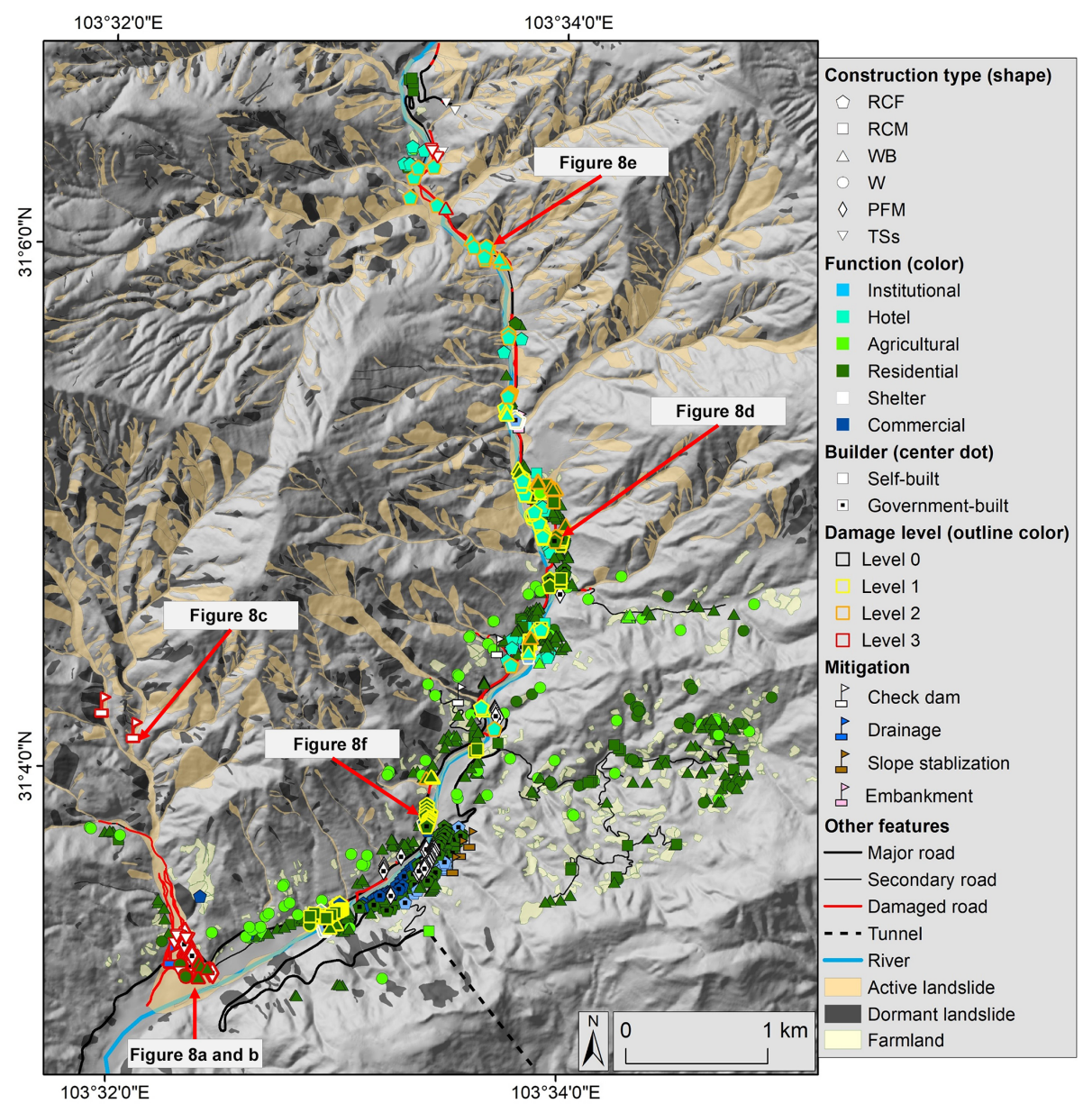

Figure 7. The building and landslide inventories mapped based on a WorldView-2 image captured in April 2011, showing the changes brought about by the August 2010 debris flow disaster. A total of 213 buildings were affected. The losses were largest for those buildings located either near subcatchment outlets or close to the river.

(Chengdu Bureau of Land and Resources, 2018). We were not able to acquire prices of farmlands, forests and other factors to estimate indirect loss. Therefore the analysis was limited to economic value, investment and direct loss caused by hazards. Severely damaged and destroyed buildings were counted as direct economic losses.

The economic value estimation result is illustrated in Fig. 11a. As a result of the fast reconstruction, the total value increased rapidly to USD 96 million in 2010 and USD 133 million in 2013, which was nearly 5 and 7 times the value in 2007 . This was caused by the increase in the number of buildings and the overall improvement in construction type; in particular the RCF buildings accounted for $75 \%$ of the total value.

The total direct loss during the monitored period was USD 16.5 million, out of which USD 8.4 million was government loss and USD 8.1 million private loss. The disaster in August 2010 caused a loss of USD 8.3 million, which was slightly more than the loss caused by the Wenchuan earthquake. This is because many expensive RCF buildings were carelessly built in areas exposed to debris flows and were severely damaged beyond repair. The loss was further increased in 2013 in the form of buildings being abandoned by the local residents in fear of debris flow and flood threats.

\subsection{Exposure}

The risk could only be expressed by the value of assets exposed to debris flows and floods, since we could not quantify the return period of the highly dynamic postearthquake hazards. The area affected by the hazards was mapped based on the landslide inventories of Tang et al. (2016) and historical flood traces found in the field. Any building located in the affected areas was considered to have an exposure potential (Fig. 11b and c). A major increase in both the value and number of exposures in 2010 suggested a careless reconstruction plan. The decrease in 2011 was caused by the impact of the 2010 debris flow. After the debris flow, Longchi adapted to the postearthquake environment by initiating multiple mitigation projects and invested USD 5 mil- 


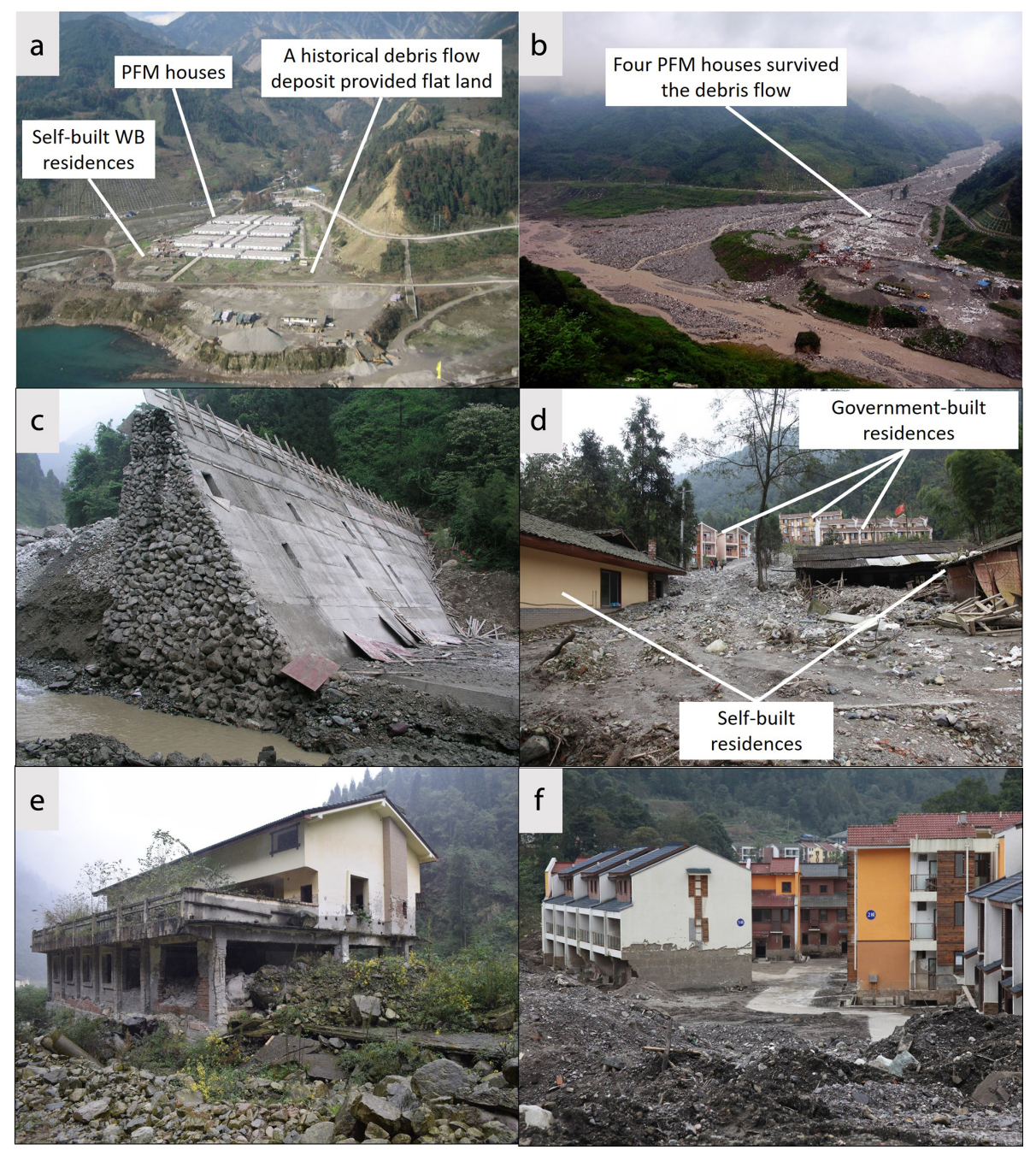

Figure 8. Losses caused by the 14 August 2010 debris flows. The locations of the examples are shown in Fig. 7. (a) The temporary settlement at the Bayi subcatchment outlet in 2009 (Luo et al., 2010). (b) The shelters destroyed by a debris flow from the Bayi subcatchment (Luo et al., 2010). (c) One of the two underdesigned check dams in Bayi subcatchment which were destroyed (Liu et al., 2010). (d) Residences reconstructed on old debris flow deposits which were damaged. (e) A hotel beside the Longxi River was struck. (f) Government-built apartment buildings beside the river which were damaged.

lion (Fig. 11b). By 2015 the majority of exposed buildings were protected by mitigation structures.

\subsection{Economy}

The economy is described based on interviews with the local residents and authorities. The economy prior to the earthquake relied mostly on farming, tourism and working outside of the town. Forestry was an important economic activity in the heavily forested watershed of the Longchi River, with trees producing medicines, nuts and building materials. Agriculture and tourism were almost equally important, generating a gross output value of USD 6.9 million for the year of 1999 (Baidu Encyclopedia, 2016).
After the earthquake, the government distributed subsidies to the residents based on the reported property damage and organized several companies to employ local people. Of the families interviewed, $29 \%$ completely or partially relied on working outside of the area in 2018, which was $9 \%$ higher than in the preearthquake situation.

Tourism was stopped completely due to the earthquake and only started recovering in 2015 . Severe losses were experienced after the reconstruction of hotels, as many were damaged by debris flows and floods, and they were unable to attract tourists because the valley was considered a dangerous place to visit. Although business started flowing 7 years after the earthquake, a full recovery was only expected upon the reopening of the national park. 


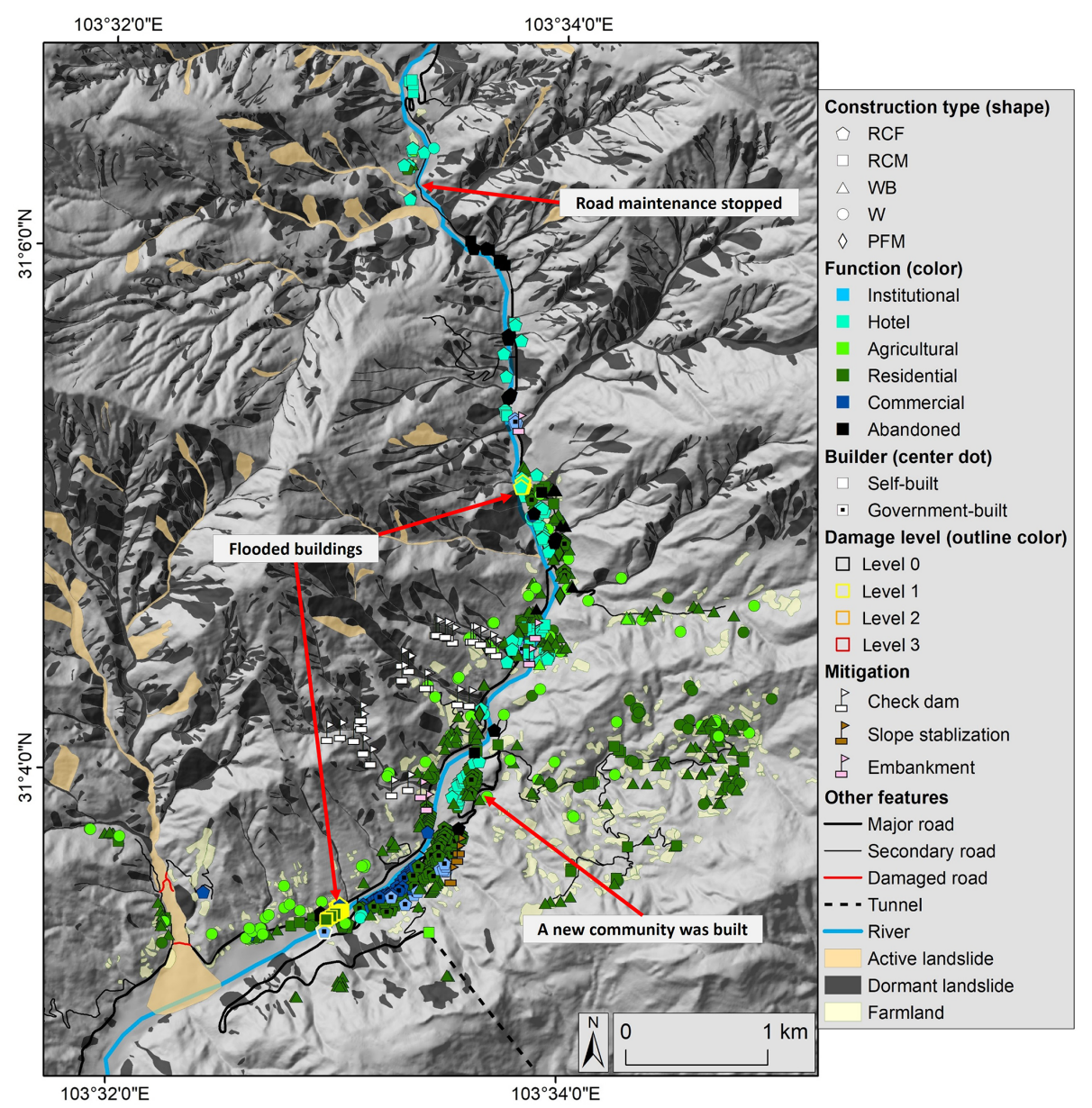

Figure 9. The inventory mapped based on the 2013 Pléiades image, showing the situation shortly after the official announcement of reconstruction completion. A new community that was built to make up the loss caused by the 2010 debris flow and many mitigation measures that were installed are shown. The debris flows caused a rise of the riverbed and led to flooding, the location of which is indicated.

The economy was more reliant on agriculture than tourism after the earthquake. From 2007 to 2018, the farmlands increased from 76 to $98 \mathrm{ha}$, and most of them grew commercial crops. Sixty-five new agricultural buildings were built after the 2010 disaster, and many were used to house domestic animals such as chicken, ducks and goats.

\section{Discussion}

\subsection{Challenges faced in postearthquake reconstruction}

Some existing examples such as Haiti (Jesselyn, 2017) and Nepal (Adhikari, 2017) are known for their slow recovery process due to politics and limitations in terms of economy. Longchi showed a contrary case in which rebuilding in a very rapid manner led to severe losses. The problems are the major construction of many valuable assets in hazard-prone areas (spatial) and rebuilding too early before the environment could reach a relatively stable situation (time). The cause of these problems might be a lack of communication between the government and scientists because of the top-down political system. Authorities were not aware of the necessity of hazard and risk assessment even though sharp increases in hazards after major earthquakes were reported before 2008 (Lin et al., 2004, 2006; Nakamura et al., 2000; Liu et al., 2013).

Ideally hazard maps should be updated shortly after earthquakes, considering the enhanced hazards and hazard chains (Fan et al., 2019a; Tang et al., 2016; Hovius et al., 2011; Marc et al., 2015) as well as long-term dynamics. Upon acquiring hazard maps, multicriteria analysis could be used to assess suitability for reconstruction planning; see for example Barić et al. (2006) and Store and Kangas (2001). The possible consequences and potential risk of the plans could be analyzed by land use models; see for example Cammerer et al. (2012) and Promper et al. (2014).

The major difficulties of reconstruction planning may lie in hazard assessment, due to the spatial and temporal dynamics of hazards as well as their interactions (Fuchs et al., 


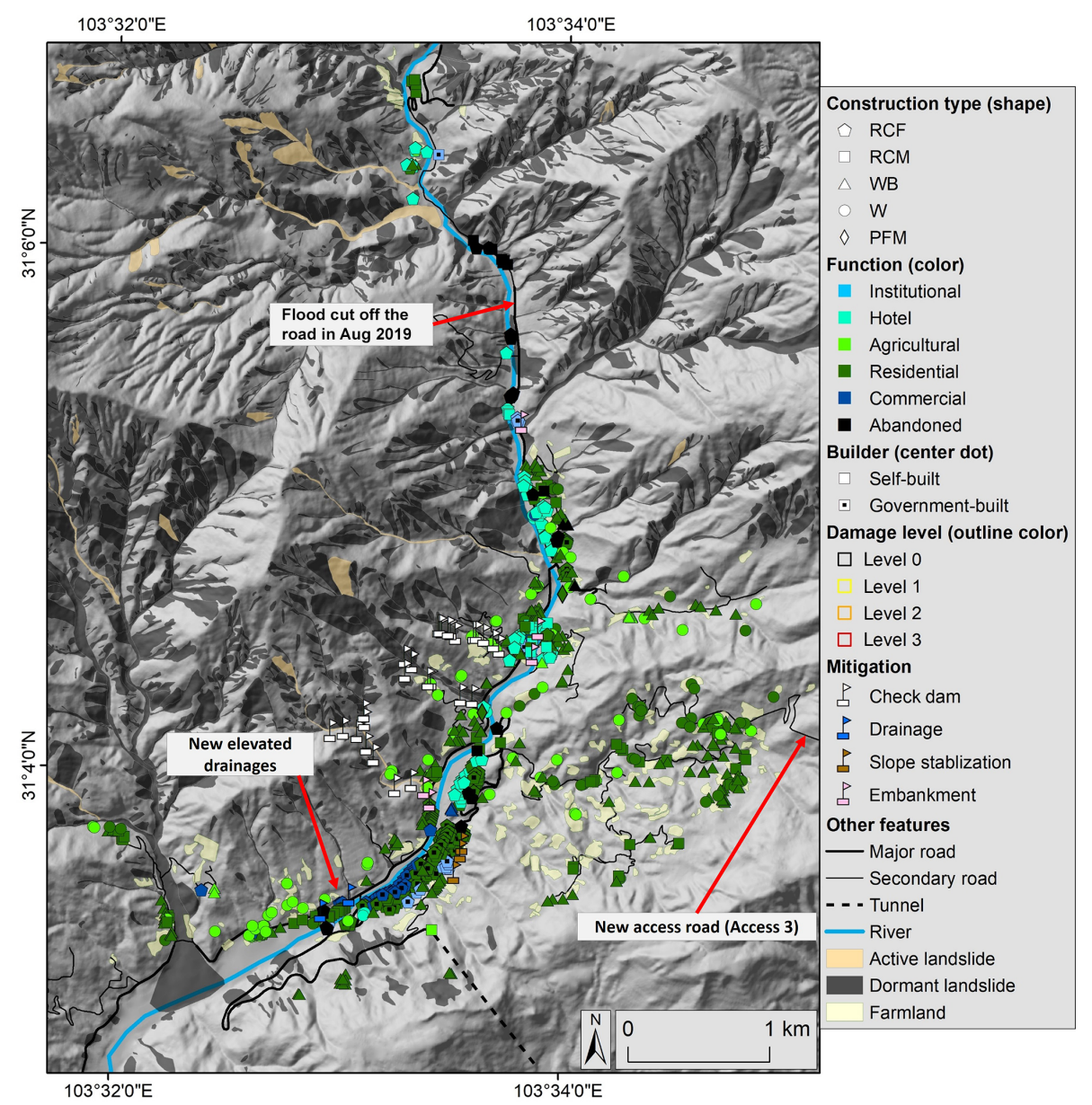

Figure 10. The inventory made based on the 2018 Pléiades image, overlaid with landslide polygons made based on the standards of Tang et al. (2016). The location of the last reported disaster, where a flood cut off the dirt road in the north on 20 August 2019, is shown.

2012; Kappes et al., 2012). These difficulties are enlarged in a postearthquake environment as many factors change much faster than they normally do. For example sediment discharge could be several times higher (Koi et al., 2008; Hovius et al., 2011) and vegetation could regrow at a rapid speed (Yang et al., 2018; Liu et al., 2010). The commonly used evidence-based statistical assessment methods might be not valid shortly after earthquakes due to the changes in environment and triggering mechanisms of hazards (Huang and Fan, 2013; Tang et al., 2011a, b; Xu et al., 2012; Fan et al., 2019b). The application of deterministic methods would be more useful but largely depends on the efficiency of data collection.

To our knowledge there are two models (van Asch et al., 2013; Bout et al., 2018) that could simulate both the initiation and the runout as well as incorporate temporal changes in environment and therefore have the potential to model such dynamics given sufficient data. The model of van Asch et al. (2013) simulates initiation and runout of entrainmentbased debris flows and was tested in one of the subwatersheds in our study area. Bout et al. (2018) incorporated the func- tions proposed by van Asch et al. (2013), and their model allows for the simulation of interactions of hazards (earthquakes, mass movements and floods), further expanding the model's potential for postearthquake hazard assessment. An example is given by Domènech et al. (2019), as they showed a case study to simulate the temporal changes in debris flow hazard affected by material depletion, revegetation and grain coarsening.

\subsection{Exposure and mitigation}

A sharp increase in exposure was demonstrated in this study, due to rises in both the number and cost of buildings. Although many elements at risk were protected by mitigation measures against debris flows and floods or not affected, many self-built buildings are still vulnerable to earthquakes. It is hard to judge whether building more expensive RCF buildings than needed, for example buildings for commercial purposes, in such a highly earthquake-susceptible area is beneficial. On the one hand they could potentially improve the quality of life for the community if the national park can 
Table 5. Price of built-up features. All values were adjusted to the situation of 2012 by the inflation rate of Chinese yuan. * Calculated based on the mitigation design of a nearby catchment.

\begin{tabular}{|c|c|c|c|}
\hline \multicolumn{2}{|l|}{ Type } & \multicolumn{2}{|c|}{ Value } \\
\hline Construction type & Code & $\begin{array}{r}\text { Unit price } \\
\text { before } 2008 \\
\left(\mathrm{USD} \mathrm{m}^{-2}\right)\end{array}$ & $\begin{array}{r}\text { Unit price } \\
2008-2012 \\
\left(\mathrm{USD} \mathrm{m}^{-2}\right)\end{array}$ \\
\hline Reinforced-concrete frame structure & $\mathrm{RCF}$ & 217 & 415 \\
\hline Reinforced-concrete masonry & $\mathrm{RCM}$ & 144 & 200 \\
\hline Wood and brick & WB & 54 & 77 \\
\hline Wooden & $\mathrm{W}$ & 27 & 46 \\
\hline Prefabricated metal houses & PFM & - & 154 \\
\hline Tents and shacks & TSs & - & 6 \\
\hline Reinforced slopes & - & - & $205^{*}$ \\
\hline Drainage channels & - & - & $103^{*}$ \\
\hline Embankments & - & - & $362^{*}$ \\
\hline Road type & & \multicolumn{2}{|c|}{ Unit price $\left(\mathrm{USD} \mathrm{m}^{-1}\right)$} \\
\hline Major road (6 m wide) & - & \multicolumn{2}{|c|}{207} \\
\hline Secondary road ( $3 \mathrm{~m}$ wide) & - & \multicolumn{2}{|c|}{23} \\
\hline Bridge ( $5 \mathrm{~m}$ wide $)$ & - & \multicolumn{2}{|c|}{828} \\
\hline Tunnel (6 m wide road) & - & \multicolumn{2}{|c|}{5069} \\
\hline Other & & \multicolumn{2}{|c|}{ Total cost (USD) } \\
\hline Mitigation works & - & \multicolumn{2}{|c|}{4.6 million } \\
\hline
\end{tabular}

be reopened in the future; on the other hand this increases the elements exposed to earthquake enormously in terms of economic value (Fig. 11a). It is advised to keep a close track of the changes in elements at risk and hazard in order to understand the up-to-date risk situation. Automatic extractions could help this task if image data could be systematically collected and well georeferenced.

Mitigation measures are widely used to reduce massmovement hazard (Fuchs et al., 2004; Keiler et al., 2006; Hübl et al., 2005; Chen et al., 2015) but only when they are properly designed. An example of failure was shown in this study (Fig. 8c), as the magnitude of the 2010 debris flow exceeded the mitigation capacity. Such mitigation might create a false sense of security and possibly leading to more losses (Olugunorisa, 2009; Cigler, 2009). It might be not beneficial to start installing mitigation measures right after an earthquake, as the magnitude and frequency of mass-movement hazards might be too costly to mitigate. A great deal of research has shown that mass-movement hazard activities decrease rapidly after 3-5 years (Fan et al., 2019a; Tang et al., 2016; Marc et al., 2015; Hovius et al., 2011); therefore a delay in mitigation and reconstruction could give more beneficial results than taking measures immediately after large earthquakes in cases where avoiding building in risky areas is not possible.

\section{Conclusions}

We monitored the changes in the Longxi valley over an 11year period after the Wenchuan earthquake and during the subsequent recovery process, with seven inventories from different years containing buildings, roads, land use and mitigation measures. Most of the stronger building construction types were only implemented after the earthquake, and mitigation structures were only installed after being impacted by debris flows and floods. A greater awareness of the benefits of avoiding living in hazard-prone areas was observed after the 2010 debris flows. Despite the extensive and repeated damage, the earthquake and subsequent landslides, debris flows, and floods gave Longchi a chance to increase its resistance to these hazards in the future and to improve economically. This outcome is called development recovery (Davis and Alexander, 2016), which not only results in the restoration of all the recovery sectors but also improves on what used to exist.

Due to the direct involvement of the government and the city of Shanghai, who supported Longxi financially and with expertise, the recovery was fast, considering the large loss and the mountainous terrain in the area impacted by the Wenchuan earthquake. The lack of experience of dealing with postearthquake landslides was the largest flaw in the recovery planning. The damage caused by postseismic landslides was not restricted to Longxi but also reported across the entire earthquake-affected region. The postearthquake 
(a) Statistics of built-up features

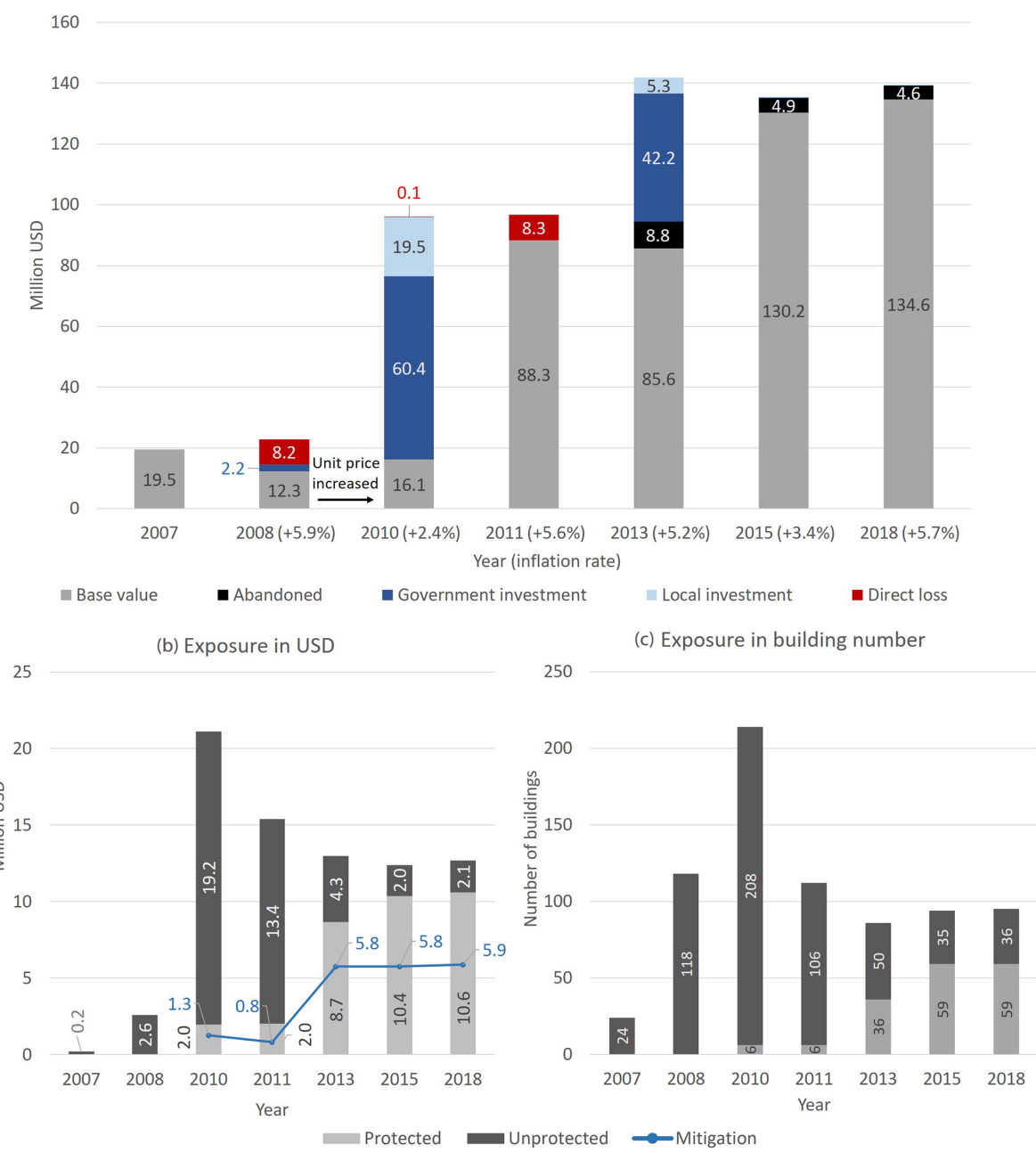

Figure 11. (a) The total values of the built-up features, investments and direct economic losses over the period between 2007 and 2018 in the Longxi area. (b) The total value of elements at risk exposed to debris flows and floods. The blue line indicates the amount of investment in mitigation measures. The values were adjusted with the inflation rate. (c) The total number of buildings that are exposed to debris flows and floods.

Table 6. Suitability of actions after earthquakes, using the Longxi watershed as an example. The numbers denote the following: $0=$ not suitable; $1=$ somewhat suitable; $2=$ suitable.

\begin{tabular}{lllll}
\hline Period and actions & \multicolumn{4}{c}{ Postseismic landslide threat } \\
\cline { 2 - 5 } & Very high & $\begin{array}{l}\text { High and } \\
\text { fast decay }\end{array}$ & $\begin{array}{l}\text { Low and } \\
\text { slow decay }\end{array}$ & $\begin{array}{l}\text { Fully } \\
\text { recovered }\end{array}$ \\
\hline Period number & I & II & III & IV \\
Timing in the Longxi watershed & $2008-2010$ & $2010-2015$ & $2015-?$ & Unknown \\
Rebuild in risky zones with mitigation & 0 & 0 & 1 & 2 \\
Rebuild in safe zones & 1 & 2 & 2 & 2 \\
Install mitigation works & 0 & 1 & 2 & 1 \\
Reopen tourism & 0 & 0 & 1 & 2 \\
Hazard surveys frequency & Very High & High & Moderate & Same as preearthquake \\
\hline
\end{tabular}


disasters did not significantly slow down the reconstruction process because of the strong economy of China and the large amount of funding that was invested in reconstruction and protection using mitigation structures.

However, recovering the economy through tourism was a failure in Longchi because postseismic debris flow activity was underestimated. Many resources were wasted, for example the destroyed and abandoned hotels, the destroyed main road, and the revoked highway entrance. Similarly, despite a handful of success examples, many unused and often destroyed tourism facilities can be seen all over the earthquakeaffected area. Among all the towns that had planned tourism, Longchi had one of the worst levels of failure because its biggest attraction was the national park which could not be reopened. The recovery would have been much more efficient if it had included an awareness of risk management. However, the question remains if these hazard reactivations could have been predicted and mitigated properly.

In such a mountainous region it is recommended not to rebuild near the outlet of catchments containing many coseismic landslides. Limiting reconstruction too close to rivers is also recommended to avoid floods caused by riverbed raising and landslide dams. Avoiding building critical structures and residential buildings near major faults, like the YingxiuBeichuan fault shown in Fig. 3, could lower the risk posed by earthquakes. The exact areas susceptible to hazards should be acquired by conducting hazard assessments.

A possible timetable for recovery actions is presented in Table 6. Four postseismic phases are identified based on landslide activity from Tang et al. (2016) and Fan et al. (2018). Period I (very high) means the period when the majority of coseismic material in streams is not depleted and loosened slope materials have not failed. Period II (high and fast decay) means the time after the first major massmovement event which removes the majority of the stream blockages. Landslides occur frequently but are not likely to have a catastrophic magnitude in this phase. Period III (low and slow decay) is when vegetation has mostly recovered and landslide activity is no longer frequently observed. Landslide activity is much lower compared with the previous two phases and slowly decays towards the preearthquake level but still poses a significant threat. Period IV (fully recovered) is when landslide activity is at the same level as the preearthquake rate.
In period I, rebuilding should be strictly limited to areas with low disaster threat. Even then risk still exists since rivers could be dammed by mass movement and cause flooding in areas outside of landslide-prone zones. It might not be appropriate to install mitigation works unless it is absolutely necessary because of expensive cost and the high magnitude of hazards. Hazards, particularly mass movements, should be closely monitored in order to respond to emergencies in a timely manner. In period II, extreme disasters are less likely to occur but building in landslide-prone areas is still too risky. Mitigation works could be installed in key locations to maintain critical infrastructures. In noncritical locations it is not beneficial to install mitigation works yet due to the large amount of coseismic debris that could still easily be activated by rainfall. It is still necessary to closely monitor hazards. Period III is the optimal time to install mitigation measures since the mass-movement threat is relatively low and therefore easier to control. Buildings are allowed to be constructed in risky areas under the protection of mitigation measures in order to utilize the limited space in a mountainous area. Reopening tourism is possible during dry seasons but should be limited during wet seasons, which could be periods of monsoon, tropical cyclone and ice melting. In period IV, the environment is fully recovered and construction plans and hazard survey can be carried out as in the preearthquake situation.

It could be concluded that hazard and risk assessment are necessary for a properly conducted postearthquake recovery. The assessments should consider not only the spatial but also the temporal dynamics of hazards, as well as the possible interaction among different hazard types, so that proper locations and suitable times for reconstruction can be identified. 


\section{Appendix A: The elements-at-risk inventory of 2007}

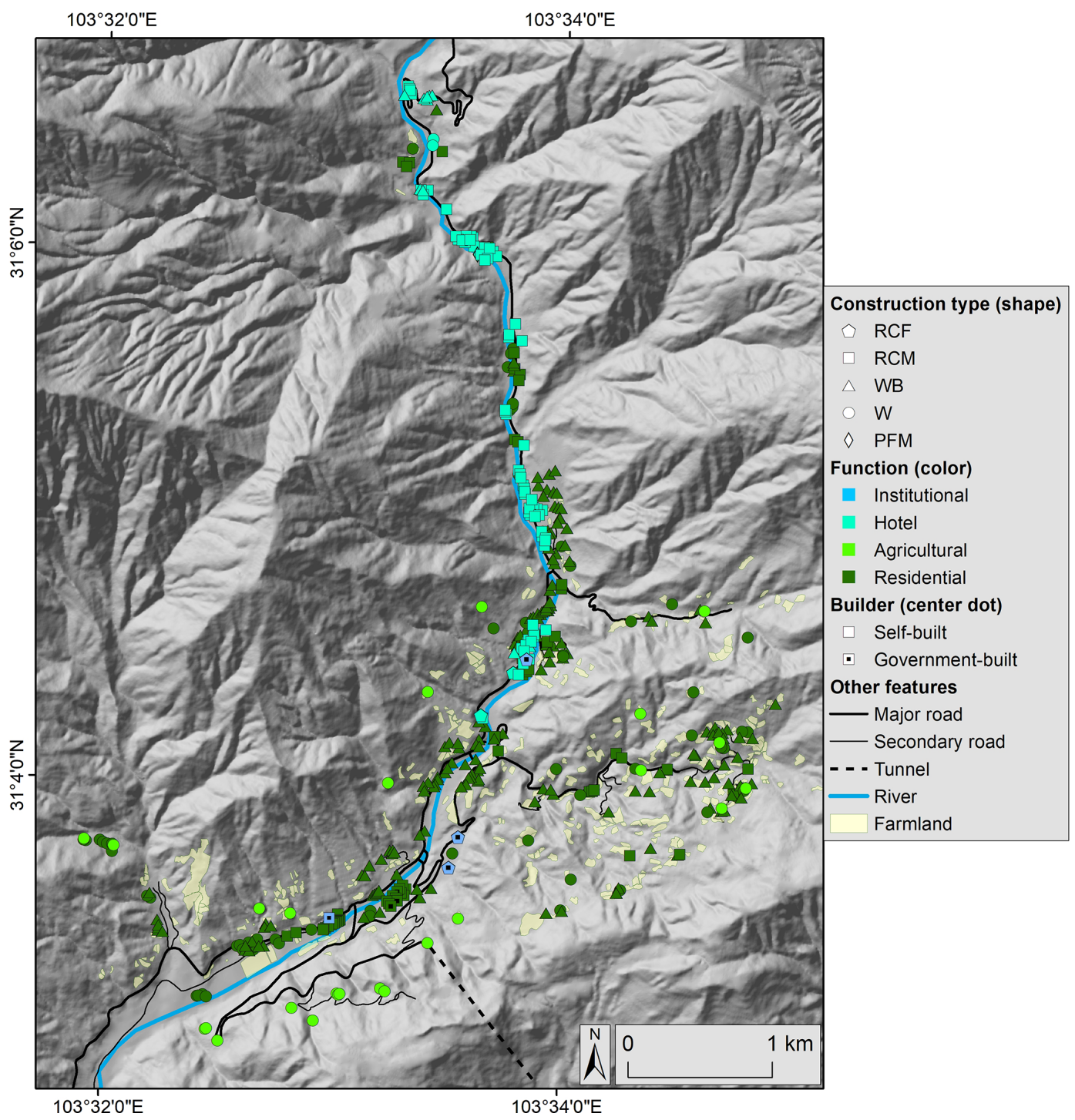

Figure A1. A figure showing the situation in 2007, before the Wenchuan earthquake. Most buildings were self-built by local residents, and many adopted WB and W construction types. Most of the region was densely covered by vegetation, and no active landslide was observed. 
Data availability. The and elements-at-risk inventories are https://doi.org/10.13140/RG.2.2.16969.70242 2020).

Author contributions. This work was carried out by CheT as part of his $\mathrm{PhD}$ thesis under the supervision of CVW. The field investigation and mapping were carried out by CheT, XL, YC, YY, HT and CY. ChuT provided resources and data.

Competing interests. The authors declare that they have no conflict of interest.

Acknowledgements. We would like to thank the two anonymous reviewers for their helpful comments and suggestions.

Financial support. This research has been supported by the National Key Research and Development Program of China (grant no. 2017YFC1501004) and the National Natural Science Foundation of China (grant no. 41672299).

Review statement. This paper was edited by Sven Fuchs and reviewed by two anonymous referees.

\section{References}

Adhikari, N.: Nepal's earthquake disaster: Two years and $\$ 4.1 \mathrm{bn}$ later, available at: https: //www.aljazeera.com/indepth/opinion/2017/04/ nepal-earthquake-disaster-years-41bn-170412110550808.html (last access: 27 April 2020), 2017.

Baidu Encyclopedia: Longchi Town (Dujiangyan city, Sichuan province), 2016.

Barić, D., Radačić, Ž., and Čurepić, D.: Implementation of multicriteria decision-making method in selecting the railway line for reconstruction, in: International Conference on Traffic Science ICTS 2006 "Transportation Logistics in Science and Practice", 6-7 December 2006, Portorož, Slovenija, 2006.

Bout, B., Lombardo, L., van Westen, C. J., and Jetten, V. G.: Integration of two-phase solid fluid equations in a catchment model for flashfloods, debris flows and shallow slope failures, Environ. Model. Softw., 105, 1-16, https://doi.org/10.1016/j.envsoft.2018.03.017, 2018.

Cammerer, H., Thieken, A. H., and Verburg, P. H.: Spatio-temporal dynamics in the flood exposure due to land use changes in the Alpine Lech Valley in Tyrol (Austria), Nat. Hazards, 68, 12431270, https://doi.org/10.1007/s11069-012-0280-8, 2012.

Chen, H. and Hawkins, A. B.: Relationship between earthquake disturbance, tropical rainstorms and debris movement: an overview from Taiwan, Bull. Eng. Geol. Environ., 68, 161-186, https://doi.org/10.1007/s10064-009-0209-y, 2009.
Chen, X., Cui, P., You, Y., Chen, J., and Li, D.: Engineering measures for debris flow hazard mitigation in the Wenchuan earthquake area, Eng. Geol., 194, 73-85, https://doi.org/10.1016/j.enggeo.2014.10.002, 2015.

Cheng, J. D., Huang, Y. C., Wu, H. L., Yeh, J. L., and Chang, C. H.: Hydrometeorological and landuse attributes of debris flows and debris floods during typhoon Toraji, July 29-30, 2001 in central Taiwan, J. Hydrol., 306, 161-173, https://doi.org/10.1016/j.jhydrol.2004.09.007, 2005.

Chengdu Bureau of Land and Resources: List of mitigations in Longchi, Chengdu, 2018.

Cigler, B. A.: Post-Katrina Hazard Mitigation on the Gulf Coast, Publ. Organiz. Rev., 9, 325-341, https://doi.org/10.1007/s11115009-0095-6, 2009.

Cui, P., Xiang, L.-Z., and Zou, Q.: Risk assessment of highways affected by debris flows in Wenchuan earthquake area, J. Mount. Sci., 10, 173-189, https://doi.org/10.1007/s11629-013-2575-y, 2013.

Dai, F. C., Xu, C., Yao, X., Xu, L., Tu, X. B., and Gong, Q. M.: Spatial distribution of landslides triggered by the 2008 Ms 8.0 Wenchuan earthquake, China, J. Asian Earth Sci., 40, 883-895, https://doi.org/10.1016/j.jseaes.2010.04.010, 2011.

Dalen, K., Flatø, H., Liu, J., and Zhang, H.: Recovering from the Wenchuan earthquake: Living Conditions and Development in Disaster Areas 2008-2011, Fafo, Oslo, 2012.

Davis, I. and Alexander, D.: Recovery from Disaster, Routledge, London, New York, 2016.

Domènech, G., Fan, X., Scaringi, G., van Asch, T. W. J., Xu, Q., Huang, R., and Hales, T. C.: Modelling the role of material depletion, grain coarsening and revegetation in debris flow occurrences after the 2008 Wenchuan earthquake, Eng. Geol., 250, 34 44, https://doi.org/10.1016/j.enggeo.2019.01.010, 2019.

Dong, J.-J., Li, Y.-S., Kuo, C.-Y., Sung, R.-T., Li, M.-H., Lee, C.T., Chen, C.-C., and Lee, W.-R.: The formation and breach of a short-lived landslide dam at Hsiaolin village, Taiwan - part I: Post-event reconstruction of dam geometry, Eng. Geol., 123, 4059, https://doi.org/10.1016/j.enggeo.2011.04.001, 2011.

Dunford, M. and Li, L.: Earthquake reconstruction in Wenchuan: Assessing the state overall plan and addressing the 'forgotten phase', Appl. Geogr., 31, 998-1009, https://doi.org/10.1016/j.apgeog.2011.01.001, 2011.

Fan, X., Tang, C. X., van Westen, C. J., and Alkema, D.: Simulating dam-breach flood scenarios of the Tangjiashan landslide dam induced by the Wenchuan Earthquake, Nat. Hazards Earth Syst. Sci., 12, 3031-3044, https://doi.org/10.5194/nhess12-3031-2012, 2012.

Fan, X., Domènech, G., Scaringi, G., Huang, R., Xu, Q., Hales, T. C., Dai, L., Yang, Q., and Francis, O.: Spatio-temporal evolution of mass wasting after the $2008 \mathrm{Mw} 7.9$ Wenchuan earthquake revealed by a detailed multi-temporal inventory, Landslides, 15 , 2325-2341, https://doi.org/10.1007/s10346-018-1054-5, 2018.

Fan, X., Scaringi, G., Domènech, G., Yang, F., Guo, X., Dai, L., He, C., Xu, Q., and Huang, R.: Two multi-temporal datasets that track the enhanced landsliding after the 2008 Wenchuan earthquake, Earth Syst. Sci. Data, 11, 35-55, https://doi.org/10.5194/essd-1135-2019, 2019a.

Fan, X., Scaringi, G., Korup, O., Joshua West, A., Westen, C. J., Tanyas, H., Hovius, N., Hales, T., W. Jibson, R., E. Allstadt, K., Zhang, L., Evans, S., Xu, C., Li, G., Pei, X., Xu, Q., and 
Huang, R.: Earthquake-induced chains of geologic hazards: patterns, mechanisms, and impacts, Rev. Geophys., 57, 421-503, https://doi.org/10.1029/2018RG000626, 2019b.

Fell, R.: Landslide risk assessment and acceptable risk, Can. Geotech. J., 31, 261-272, 1993.

Fuchs, S., Bründl, M., and Stötter, J.: Development of avalanche risk between 1950 and 2000 in the Municipality of Davos, Switzerland, Nat. Hazards Earth Syst. Sci., 4, 263-275, https://doi.org/10.5194/nhess-4-263-2004, 2004.

Fuchs, S., Keiler, M., Sokratov, S., and Shnyparkov, A.: Spatiotemporal dynamics: the need for an innovative approach in mountain hazard risk management, Nat. Hazards, 68, 1217-1241, https://doi.org/10.1007/s11069-012-0508-7, 2012.

Gorum, T., Fan, X., van Westen, C. J., Huang, R. Q., $\mathrm{Xu}$, Q., Tang, C., and Wang, G.: Distribution pattern of earthquake-induced landslides triggered by the 12 May 2008 Wenchuan earthquake, Geomorphology, 133, 152-167, https://doi.org/10.1016/j.geomorph.2010.12.030, 2011.

Guo, X., Cui, P., Li, Y., Ma, L., Ge, Y., and Mahoney, W. B.: Intensity-duration threshold of rainfall-triggered debris flows in the Wenchuan Earthquake affected area, China, Geomorphology, 253, 208-216, https://doi.org/10.1016/j.geomorph.2015.10.009, 2016.

Hovius, N., Meunier, P., Lin, C.-W., Chen, H., Chen, Y.G., Dadson, S., Horng, M.-J., and Lines, M.: Prolonged seismically induced erosion and the mass balance of a large earthquake, Earth Planet. Sc. Lett., 304, 347-355, https://doi.org/10.1016/j.epsl.2011.02.005, 2011.

$\mathrm{Hu}$, T. and Huang, R.-q.: A catastrophic debris flow in the Wenchuan Earthquake area, July 2013: characteristics, formation, and risk reduction, J. Mount. Sci., 14, 15-30, https://doi.org/10.1007/s11629-016-3965-8, 2017.

Hu, X., Salazar, M., Zhang, Q., Lu, Q., and Zhang, X.: Social Protection during Disasters: Evidence from the Wenchuan Earthquake, IDS Bulletin, 41, 107-115, https://doi.org/10.1111/j.1759-5436.2010.00157.x, 2010.

Huang, R. and Fan, X.: The landslide story, Nat. Geosci., 6, 325326, https://doi.org/10.1038/ngeo1806, 2013.

Huang, Y., Zhou, L., and Wei, K.: 5.12 Wenchuan earthquake recovery government policies and non-governmental organizations' participation, Asia Pacif. J. Social Work Dev., 21, 77-91, 2011.

Hübl, J., Fiebiger, G., Jakob, M., and Hungr, O.: Debris-flow mitigation measures, in: Debris-flow Hazards and Related Phenomena, edited by: Jakob, M. and Hungr, O., Springer, Berlin, Heidelberg, 445-487, 2005.

Jesseln, C.: 7 Years After Haiti's Earthquake, Millions Still Need Aid, available at: https://www.huffpost.com/entry/ haiti-earthquake-anniversary_n_5875108de4b02b5f858b3f9c (last access: 27 April 2020), 2017.

Kappes, M. S., Keiler, M., von Elverfeldt, K., and Glade, T.: Challenges of analyzing multi-hazard risk: a review, Nat. Hazards, 64, 1925-1958, https://doi.org/10.1007/s11069-012-0294-2, 2012.

Keiler, M., Sailer, R., Jörg, P., Weber, C., Fuchs, S., Zischg, A., and Sauermoser, S.: Avalanche risk assessment - a multitemporal approach, results from Galtür, Austria, Nat. Hazards Earth Syst. Sci., 6, 637-651, https://doi.org/10.5194/nhess-6637-2006, 2006.

Koi, T., Hotta, N., Ishigaki, I., Matuzaki, N., Uchiyama, Y., and Suzuki, M.: Prolonged impact of earthquake-induced landslides on sediment yield in a mountain watershed: The Tanzawa region, Japan, Geomorphology, 101, 692-702, https://doi.org/10.1016/j.geomorph.2008.03.007, 2008.

Kun, P., Han, S., Chen, X., and Yao, L.: Prevalence of posttraumatic stress disorder in Sichuan province China after the 2008 Wenchuan earthquake, Publ. Health, 123, 703-707, https://doi.org/10.1016/j.puhe.2009.09.017, 2009.

Li, D., Hao, H., Ma, j., Wu, X., Yan, Z., Li, G., Wang, H., Gao, J., Liu, H., Huang, Y., Yang, X., Zeng, Z., Liu, J., Gao, L., Shen, T., Cao, N., Zhang, Y., Li, Z., Liu, K., Li, D., and Xian, Z.: Emergency hazard mitigation design of the catastrophic Hongchun catchment debris flow, Yingxiu, Wenchuan county, Guanghan Geological Engineering Survey, Guanghan, 2011.

Li, L., Yao, X., Zhang, Y., Iqbal, J., Chen, J., and Zhou, N.: Surface recovery of landslides triggered by 2008 Ms8.0 Wenchuan earthquake (China): a case study in a typical mountainous watershed, Landslides, 13, 787-794, https://doi.org/10.1007/s10346015-0594-1, 2016.

Li, Y., Huang, R., Yan, L., Densmore, A., and Zhou, R.: Surface Rupture and Hazard of Wenchuan Ms 8.0 Earthquake, Sichuan, China, Int. J. Geosci., 1, 21-31, https://doi.org/10.4236/ijg.2010.11003, 2010.

Lin, C. W., Shieh, C. L., Yuan, B. D., Shieh, Y. C., Liu, S. H., and Lee, S. Y.: Impact of Chi-Chi earthquake on the occurrence of landslides and debris flows: example from the Chenyulan River watershed, Nantou, Taiwan, Eng. Geol., 71, 49-61, 2004.

Lin, C.-W., Liu, S.-H., Lee, S.-Y., and Liu, C.-C.: Impacts of the Chi-Chi earthquake on subsequent rainfallinduced landslides in central Taiwan, Eng. Geol., 86, 87-101, https://doi.org/10.1016/j.enggeo.2006.02.010, 2006.

Liu, S.-H., Lin, C.-W., and Tseng, C.-M.: A statistical model for the impact of the 1999 Chi-Chi earthquake on the subsequent rainfall-induced landslides, Eng. Geol., 156, 11-19, https://doi.org/10.1016/j.enggeo.2013.01.005, 2013.

Liu, Y., Liu, R., and Ge, Q.: Evaluating the vegetation destruction and recovery of Wenchuan earthquake using MODIS data, Nat. Hazards, 54, 851-862, https://doi.org/10.1007/s11069-0109511-z, 2010.

Lo, A. Y. and Cheung, L. T. O.: Seismic risk perception in the aftermath of Wenchuan earthquakes in southwestern China, Nat. Hazards, 78, 1979-1996, https://doi.org/10.1007/s11069-015-18156, 2015.

Luo, M., Wei, C., Mo, J., Liao, W., Liang, J., Long, B., Wang, M., Li, H., Zhang, Y., Zhong, J., Wu, F., and Zhang, G.: Investigation report on geological hazards in dujiangyan city (Unpublished, in Chinese), Sichuan Geological Survey Institute, Sichuan, 2010.

Marc, O., Hovius, N., Meunier, P., Uchida, T., and Hayashi, S.-I.: Transient changes of landslide rates after earthquakes, Geology, 43, 883-886, https://doi.org/10.1130/g36961.1, 2015.

Nakamura, H., Tsuchiya, S., and Inoue, K.: Sabo against Earthquakes, Kokon Shoin, Tokyo, Japan, 2000.

Ni, H., Zheng, W., Song, Z., and Xu, W.: Catastrophic debris flows triggered by a 4 July 2013 rainfall in Shimian, SW China: formation mechanism, disaster characteristics and the lessons learned, Landslides, 11, 909-921, https://doi.org/10.1007/s10346-0140514-9, 2014.

Olugunorisa, T.: Strategies for mitigation of flood risk in the Niger Delta, Nigeria, J. Appl. Sci. Environ. Manage., 13, https://doi.org/10.4314/jasem.v13i2.55295, 2009. 
Promper, C., Puissant, A., Malet, J. P., and Glade, T.: Analysis of land cover changes in the past and the future as contribution to landslide risk scenarios, Appl. Geogr., 53, 11-19, https://doi.org/10.1016/j.apgeog.2014.05.020, 2014.

Shieh, C. L., Chen, Y. S., Tsai, Y. J., and Wu, J. H.: Variability in rainfall threshold for debris flow after the Chi-Chi earthquake in central Taiwan, China, Int. J. Sediment Res., 24, 177-188, https://doi.org/10.1016/S1001-6279(09)60025-1, 2009.

Shou, K. J., Hong, C. Y., Wu, C. C., Hsu, H. Y., Fei, L. Y., Lee, J. F., and Wei, C. Y.: Spatial and temporal analysis of landslides in Central Taiwan after 1999 Chi-Chi earthquake, Eng. Geol., 123, 122-128, https://doi.org/10.1016/j.enggeo.2011.03.014, 2011.

Sichuan Geology Engineering Reconnaissance Institute: Hazard survey report of the 13 Aug Shuida catchment debris flow, Chengdu, 2010.

Sichuan Geology Engineering Reconnaissance Institute: Hazard survey report of the Maliu gully debris flow after the Aug 132010 disaster in Longchi town, Chengdu, 2011.

Sichuan Geological Survey: Hazard survey report of the Huangyang gully debris flows in the Wenchuan-earthquake-hit area, Chengdu, 2010.

Stevens, C., McCaffrey, R., Silver, E., Sombo, Z., English, P., and Van der Kevie, J.: Mid-crustal detachment and ramp faulting in the Markham Valley, Papua New Guinea, Geology, 26, 847-850, 1998.

Store, R. and Kangas, J.: Integrating spatial multi-criteria evaluation and expert knowledge for GIS-based habitat suitability modelling, Landsc. Urban Plan., 55, 79-93, https://doi.org/10.1016/S0169-2046(01)00120-7, 2001.

Sun, M., Chen, B., Ren, J., and Chang, T.: Natural Disaster's Impact Evaluation of Rural Households' Vulnerability: The case of Wenchuan earthquake, Agr. Agricult. Sci. Procedia, 1, 52-61, https://doi.org/10.1016/j.aaspro.2010.09.007, 2010a.

Sun, M., Chen, B., and Shi, G.: Comparative analysis of influence factors for household income before and after the natural disaster: a study of Wenchuan, Technology Economics, 19, $2010 \mathrm{~b}$.

Tang, C., Zhu, J., Ding, J., Cui, X. F., Chen, L., and Zhang, J. S.: Catastrophic debris flows triggered by a 14 August 2010 rainfall at the epicenter of the Wenchuan earthquake, Landslides, 8, 485497, https://doi.org/10.1007/s10346-011-0269-5, 2011a.

Tang, C., Zhu, J., Qi, X., and Ding, J.: Landslides induced by the Wenchuan earthquake and the subsequent strong rainfall event: A case study in the Beichuan area of China, Eng. Geol., 122, 22-33, 2011b.

Tang, C., van Asch, T. W. J., Chang, M., Chen, G. Q., Zhao, X. H., and Huang, X. C.: Catastrophic debris flows on 13 August 2010 in the Qingping area, southwestern China: The combined effects of a strong earthquake and subsequent rainstorms, Geomorphology, 139-140, 559-576, https://doi.org/10.1016/j.geomorph.2011.12.021, 2012.

Tang, C., Van Westen, C. J., Tanyas, H., and Jetten, V. G.: Analysing post-earthquake landslide activity using multi-temporal landslide inventories near the epicentral area of the 2008 Wenchuan earthquake, Nat. Hazards Earth Syst. Sci., 16, 2641-2655, https://doi.org/10.5194/nhess-16-2641-2016, 2016.

Tang, C., Tanyas, H., van Westen, C. J., Tang, C., Fan, X., and Jetten, V. G.: Analysing post-earthquake mass movement volume dynamics with multi-source DEMs, Eng. Geol., 248, 89-101, https://doi.org/10.1016/j.enggeo.2018.11.010, 2019.
Tang, C. X., Liu, X., Cai, Y., Westen, C. J., Yang, Y., Tang, H., Yang, C. Z., and Tang, C.: Element-at-risk inventory of Longchi 20072018 v0.1, https://doi.org/10.13140/RG.2.2.16969.70242, 2020.

Tanyas, H., Westen, C. J., Persello, C., and Alvioli, M.: Rapid prediction of the magnitude scale of landslide events triggered by an earthquake, Landslides, 16, 661-676, https://doi.org/10.1007/s10346-019-01136-4, 2019.

UNISDR - United Nations Office for Disaster Risk Reduction: Wenchuan earthquake 2008: recovery and reconstruction in Sichuan province, Kobe, Japan, 2010.

van Asch, T. W. J., Tang, C., Alkema, D., Zhu, J., and Zhou, W.: An integrated model to assess critical rainfall thresholds for run-out distances of debris flows, Nat. Hazards, 70, 299-311, https://doi.org/10.1007/s11069-013-0810-z, 2013.

van Westen, C. J., van Asch, T. W. J., and Soeters, R.: Landslide hazard and risk zonation - why is it still so difficult?, Bull. Eng. Geol. Environ., 65, 167-184, https://doi.org/10.1007/s10064005-0023-0, 2006.

Varnes, D. J.: Landslide Hazard Zonation: a review of principles and practice, UNESCO, Paris, France, 1984.

Wang, F., Cheng, Q., Highland, L., Miyajima, M., Wang, H., and Yan, C.: Preliminary investigation of some large landslides triggered by the 2008 Wenchuan earthquake, Sichuan Province, China, Landslides, 6, 47-54, https://doi.org/10.1007/s10346009-0141-z, 2009

Wang, X., Ding, X., Wang, L., and Wang, Y.: Fast assessment of earthquake loss and its application to the 2008 MS8.0 Wenchuan earthquake, Earthq. Sci., 22, 129-133, https://doi.org/10.1007/s11589-009-0129-8, 2009.

Wang, Y., Zou, Z., and Li, J.: Influencing factors of households disadvantaged in post-earthquake life recovery: a case study of the Wenchuan earthquake in China, Nat. Hazards, 75, 1853-1869, https://doi.org/10.1007/s11069-014-1400-4, 2015.

Wu, J., Li, N., Hallegatte, S., Shi, P., Hu, A., and Liu, X.: Regional indirect economic impact evaluation of the 2008 Wenchuan Earthquake, Environ. Earth Sci., 65, 161-172, https://doi.org/10.1007/s12665-011-1078-9, 2012.

$\mathrm{Xu}, \mathrm{C} ., \mathrm{Xu}, \mathrm{X}$. , Yao, X., and Dai, F.: Three (nearly) complete inventories of landslides triggered by the May 12 , 2008 Wenchuan Mw 7.9 earthquake of China and their spatial distribution statistical analysis, Landslides, 11, 441-461, https://doi.org/10.1007/s10346-013-0404-6, 2014.

Xu, P., Lu, X., Zuo, K., and Zhang, H.: Post-Wenchuan Earthquake Reconstruction and Development in China, in: Disaster and Development: Examining Global Issues and Cases, edited by: Kapucu, N. and Liou, K. T., Springer International Publishing, Cham, 427-445, 2014.

Xu, Q., Zhang, S., Li, W. L., and van Asch, T. W. J.: The 13 August 2010 catastrophic debris flows after the 2008 Wenchuan earthquake, China, Nat. Hazards Earth Syst. Sci., 12, 201-216, https://doi.org/10.5194/nhess-12-201-2012, 2012.

Yang, S., Du, J., He, S., Shi, M., and Sun, X.: The emerging vulnerable population of the urbanisation resulting from post-disaster recovery of the Wenchuan earthquake, Nat. Hazards, 75, 2103 2118, https://doi.org/10.1007/s11069-014-1413-z, 2015.

Yang, W., Qi, W., Wang, M., Zhang, J., and Zhang, Y.: Spatial and temporal analyses of post-seismic landslide changes near the epicentre of the Wenchuan earthquake, Geomorphology, 276, 8-15, https://doi.org/10.1016/j.geomorph.2016.10.010, 2017. 
Yang, W., Qi, W., and Zhou, J.: Decreased post-seismic landslides linked to vegetation recovery after the 2008 Wenchuan earthquake, Ecol. Indicat., 89, 438-444, https://doi.org/10.1016/j.ecolind.2017.12.006, 2018.

Yi, P., Song, Y., Li, D., and Fu, Y.: Investigation report on debris flow in bayi cathcment, dujiangyan city, sichuan province (Unpublished work, in Chinese), Chongqing GaoXin Engineering Survey and Design Institute Ltd, Co., Chongqing, China, 2009.

Yu, B., Ma, Y., Zhang, J., Wu, Y., Zhang, H., Li, L., and Chu, S.: Debris flow hazard in Longchi after the Wenchuan earthquake, J. Mount. Sci., 6, 738-746, 2011.

Zhang, H.: Household vulnerability and economic status during disaster recovery and its determinants: a case study after the Wenchuan earthquake, Nat. Hazards, 83, 1505-1526, https://doi.org/10.1007/s11069-016-2373-2, 2016.
Zhang, S. and Zhang, L. M.: Impact of the 2008 Wenchuan earthquake in China on subsequent long-term debris flow activities in the epicentral area, Geomorphology, 276, 86-103, 2016.

Zhang, S., Zhang, L., Lacasse, S., and Nadim, F.: Evolution of Mass Movements near Epicentre of Wenchuan Earthquake, the First Eight Years, Sci. Rep., 6, 36154, https://doi.org/10.1038/srep36154, 2016.

Zhang, W., Jiang, L., Li, X., and Yang, T.: Exploration of mortality and economy vulnerability of wenchuan earthquake, J. Nat. Disast., 2, 197-204, 2013. 